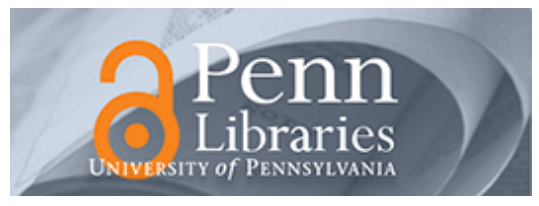

University of Pennsylvania

ScholarlyCommons

Accounting Papers

Wharton Faculty Research

6-1998

\title{
Hedging and Coordinated Risk Management: Evidence From Thrift Conversions
}

Catherine M. Schrand

University of Pennsylvania

Haluk Unal

Follow this and additional works at: https://repository.upenn.edu/accounting_papers

Part of the Accounting Commons, and the Business Administration, Management, and Operations Commons

\section{Recommended Citation}

Schrand, C. M., \& Unal, H. (1998). Hedging and Coordinated Risk Management: Evidence From Thrift Conversions. The Journal of Finance, 53 (3), 979-1013. Retrieved from https://repository.upenn.edu/ accounting_papers/47

This paper is posted at ScholarlyCommons. https://repository.upenn.edu/accounting_papers/47

For more information, please contact repository@pobox.upenn.edu. 


\title{
Hedging and Coordinated Risk Management: Evidence From Thrift Conversions
}

\author{
Abstract \\ We provide an explanation for hedging as a means of allocating rather than reducing risk. We argue that \\ firms facing a total risk constraint optimally allocate risk by reducing (increasing) exposure to risks \\ providing zero (positive) economic rents. Our evidence suggests that mutual thrifts which convert to \\ stock institutions reduce interestrate risk through improved balance sheet maturity matching and \\ increased derivatives use at the time of conversion. This interest-rate risk reduction is followed by slower \\ growth in credit risk. Post-conversion, risk management activities are significantly related to growth \\ capacity and management compensation structure attained at conversion. \\ Disciplines \\ Accounting | Business Administration, Management, and Operations
}




\section{Wharton}

Financial

Institutions

Center
$\mathrm{H}$ edging and Coordinated R isk $M$ anagement: $E$ vidence from $T$ hrift Conversions

by

Catherine M. Schrand

Haluk Unal

96-05 


\section{THE WHART ON FINAN CIAL INST ITUTIONSCENTER}

The Wharton F inancial Institutions Center provides a multi-disciplinary research approach to the problems and opportunities facing the financial services industry in its search for competitive excellence. T he Center's research focuses on the issues related to managing risk at the firm level as well as ways to improve productivity and performance.

T he Center fosters the development of a community of faculty, visiting scholars and Ph.D. candidates whose research interests complement and support the mission of the Center. The Center works closely with industry executives and practitioners to ensure that its research is informed by the operating realities and competitive demands facing industry participants as they pursue competitive excellence.

Copies of the working papers summarized here are available from the Center. If you would like to learn more about the Center or become a member of our research community, please let us know of your interest.

Anthony M. Santomero

Director

TheW orking Paper Series is made possible by a generous grant from the Alfred P. Sloan F oundation 
Hedging and Coordinated Risk M anagement:

E vidence from T hrift Conversion ${ }^{1}$

First D raft: M ay 1995

Current D raft: D ecember 1995

Abstract: We provide an explanation for hedging as a means of allocating rather than reducing risk. We argue that firms facing a total risk constraint optimally allocate risk by reducing (increasing) exposure to risks providing zero (positive) economic rents. Our evidence suggests that mutual thrifts which convert to stock institutions reduce interestrate risk through improved balance sheet maturity matching and increased derivatives use at the time of conversion. This interest-rate risk reduction is followed by slower growth in credit risk. Post-conversion, risk management activities are significantly related to growth capacity and management compensation structure attained at conversion.

${ }^{1} \mathrm{C}$ atherine $\mathrm{M}$. Schrand is at the Wharton School of the U niversity of Pennsylvania, 2425 Steinberg $\mathrm{H}$ allDietrich H all, Philadelphia, PA 19104-6315, phone (215) 898-6798. Haluk Unal is at the U niversity of M aryland at College Park, Van M unching H all, College Park, M D 20742, phone (301) 405-2256.

The first draft of this paper was completed while U nal was visiting at the Wharton School. T he authors thank seminar participants at the U niversity of Georgia, O hio State U niversity and the Wharton School. The detailed comments of Paul F ischer, M ark F lannery, Bruce Grundy, D ilip M adan, Bernadette M inton and J oseph Sinkey were especially useful. We are grateful to the Office of T hrift Supervision for providing data. 


\section{Hedging and Coordinated Risk Management: \\ Evidence from Thrift Conversions}

This paper proposes an approach for analyzing risk-management decisions when the payoffs to a firm's portfolio are exposed to multiple sources of risk. In practice, firms reduce some risks while remaining exposed to, or even seeking, other sources of risk. For example, Merck \& Co., Inc., states that reducing risk with respect to foreign exchange exposure stabilizes cash flows which allows the firm to increase risk by making investments in research and development (Lewent and Kearney, 1990). This paper provides an explanation for this observed coordination of risk management activities and evidence of this behavior in the savings and loan industry.

We consider the situation in which multiple risks are bundled within particular assets or liabilities. The risk of a firm's assets and liabilities are made up of many components such as input and output price risk, foreign exchange risk, interest-rate risk, credit risk, liquidity risk, market risk, and political risk. Firms are unable to acquire these risks separately in the spot markets. In such a case, firms that are constrained with respect to total risk coordinate their management of these multiple risks. The optimal allocation may include increasing one source of risk while decreasing another within the purchased bundle.'

Specific predictions about optimal risk allocation require structure on the definition of "risk." We segregate risk into two types based on a firm's information advantage with respect to the source of risk. Firms earn rents or economic profits for bearing risk about which the firm has a comparative information advantage (compensated risk). By contrast, there are zero economic rents associated with homogeneous risks such as unexpected changes in foreign currency rates or commodity prices (hedgeable risk). If compensated and hedgeable risks are bundled, then the firm's portfolio problem is constrained since changes in compensated risk must be associated with

"The term "allocation" is typically used in the existing literature to describe allocation of risk across parties with different risk preferences. (See Mason, 1995.) By contrast, we use the term "allocation" to represent the allocation of total risk between multiple sources such as interest-rate risk or credit risk. 
simultaneous changes in hedgeable risk. Firms, however, may effectively unbundle these risks using various cash market or derivative instruments. Almost by construction, the costs associated with managing hedgeable risks are low since the definition of "hedgeable" implies that information about the related payoffs is symmetric. Together, the positive economic rents associated with compensated risks and the low transactions costs of managing hedgeable risks suggest that optimal risk allocation is achieved by reducing hedgeable risks and increasing compensated risks. We denote this approach of optimal risk allocation as Coordinated Risk Management.

The coordinated risk management framework contrasts with current models of riskmanagement by examining risk allocation rather than risk reduction. Models such as Froot, Scharfstein and Stein (1993), and Smith and Stulz (1985) describe equilibrium scenarios in which reducing total risk associated with expected cash flows or profits is value-maximizing. These models, however, do not specify the source of variance in the distribution of wealth (or profits). Thus, they ignore multi-dimensional risks and, by definition, the possible covariation among risks within a firm. Therefore, they are unable to predict simultaneous increases and decreases in the components of total risk within a portfolio.

By contrast, this paper fits into the literature which examines multi-dimensional risks including Campbell and Kracaw (1990) and Froot and Stein (1995). In particular, Campbell and Kracaw allow for multi-dimensionality in firm risk, decomposing it into risks that are either observable or unobservable by debtholders. If the observable risks are positively correlated with the unobservable risks, they argue that creditors facing a risk of asset substitution can mitigate these agency costs by requiring the borrowing firm to hedge the observable risks. Rather than making a distinction between observable and unobservable risks, we make a distinction between hedgeable and compensated risks. Considering multi-dimensional risks using this distinction allows us to make predictions about the types of risks which are optimally hedged in a more general setting than debt issuance.

To test our predictions which result from considering coordinated risk allocation, we examine the quarterly credit and interest-rate risk decisions of 81 firms in the savings and loan 
(S\&L) industry which convert from mutual-to-stock charters between 1984 and 1988 . We restrict our sample to converting savings and loans for two reasons. First, within an S\&L, both credit risk and interest-rate risk are bundled in loans. Therefore, a thrift is forced to intermingle the management of its two most significant sources of risk in a single investment decision. Moreover, both of these risks are measurable as a result of regulatory reporting requirements. Hence, we can directly test the coordination of risk management activities. We assume that thrifts have a comparative information advantage with respect to credit risk but earn no economic rents, in expectation, with respect to interest-rate risk. Interest-rate risk (hedgeable risk) can be managed using derivative instruments. Credit risk (compensated risk) is managed through on-balance sheet strategies including project selection and diversification. Based on these definitions, we assume that interest-rate risk is relatively less costly to reduce than credit risk.

Within the S\&L industry, converting institutions provide a second advantage. The conversion process affects an institution's managerial compensation and growth capacity, both of which are predicted to be associated with risk-management incentives. (See Smith and Stulz, 1985, and Froot, Scharfstein, and Stein, 1993, respectively.) Prior to conversion, management of these institutions are typically compensated by a fixed salary. Following conversion, shareholders are able to include stock and stock options in the managers' compensation contracts. Also, at the time of conversion, the thrift obtains new capital enabling it to attain financial slack. The level of this financial slack is a choice variable by management. Hence, we can construct an ex ante measure an institution's growth capacity. Because these firm characteristics change when an institution converts, we are able to test for the association between these factors and changes in the coordination of risks following conversion. In addition, non-converting mutual and stockchartered institutions represent excellent samples to control for industry trends in risk exposure unrelated to conversion.

Within the coordinated risk management framework, we expect converting thrifts to better coordinate their risk-management activities by increasing credit risk and decreasing interest-rate risk following conversion. Consistent with this prediction, we observe that converting thrifts 
immediately increase their interest-rate risk hedging activities at the time of conversion relative to a control group of stock-chartered institutions. This reduction of interest-rate risk is attained collectively through better matching of on-balance sheet assets and liabilities (as measured by oneyear maturity gap) ${ }^{2}$ and through increased use of derivative instruments. ${ }^{3}$ On-balance sheet gap management begins approximately one year after conversion. By contrast, the significant increase in the use of derivatives begins at the time of conversion and continues thereafter. We also observe that interest-rate risk reduction is not done in isolation. Rather, credit risk also increases following conversion and is positively and significantly coordinated with the increased hedging of interestrate risk.

Further analysis shows that this observed coordination of risks following conversion is significantly related to growth capacity and managerial compensation structure attained at the time of conversion. These results support the predictions of Froot, Scharfstein, and Stein (1993) and Smith and Stulz (1985). We report that institutions which acquired greater growth capacity at the time of conversion coordinated firm risks more by reducing interest-rate risk and increasing credit risk relative to institutions anticipating low growth. Related to managerial compensation, we show that institutions with greater managerial share holdings exhibit higher coordination of risks following conversion. In addition, with respect to the management of interest-rate risk, hedging begins approximately one-year in advance of conversion only for those institutions whose managers subsequently attain high share ownership. By contrast, option holdings are negatively associated with changes in interest-rate risk management. Furthermore, those institutions whose managers have relatively greater option holdings exhibit high on-balance sheet interest-rate risk, but these institutions use derivatives extensively to reduce net interest-rate risk exposure. ${ }^{4}$

\footnotetext{
${ }^{2}$ We provide evidence that the market values of institutions which have a more negative (and more risky) maturity gap net of the impact of derivatives are more sensitive to unexpected changes in interest rates than other institutions. These market tests confirm the ability of our proxy for interest-rate risk to capture our sample institutions' exposures.

${ }^{3}$ This evidence suggests that, on average, derivatives are used to reduce rather than increase interest-rate risk contrary to the claims of those favoring additional derivatives regulation in the S\&L industry. For a thorough description of the regulatory issues, see Hansell and Muehring (1992).

${ }^{4}$ These latter results are consistent with the observed association between hedging and managerial compensation for gold mining firms (Tufano, 1995).
} 
The paper proceeds as follows. Section I discusses the coordinated management of multiple risks within a firm. Section II adapts the coordinated risk management framework to the savings and loan industry and summarizes the paper's predictions for our sample of converting thrifts. A discussion of the sample and proxy variables is presented in Section III followed by a description of the methodology and the related results in Section IV. Section V summarizes the findings.

\section{Coordinated Risk Management}

The current risk-management literature demonstrates situations in which the reduction of variance is a value maximizing activity. Models, including Froot and Stein (1995), Froot, Scharfstein and Stein (1993), and Smith and Stulz (1985) among others, propose market imperfections which provide incentives for otherwise risk-neutral firms to behave as if they are risk-averse. For example, Smith and Stulz (1985) demonstrate that a firm may choose to reduce variation in cash flows because managerial contracting costs, expected taxes and costs of financial distress are a function of this variation.

These models, however, consider the impact of only total variation in wealth or profits on firm-value. By contrast, we consider the case where total variation has multiple sources. This additional structure allows for the possibility that hedging is optimal as a means of allocating rather than reducing total firm risk. In contrast to the predictions based on the uni-dimensional notion of risk described in the existing models, we are able to explain optimal risk-reduction or hedging of certain risks even for firms attempting to increase total firm risk.

Consider a firm which is endowed at time $t=0$ with one asset having two sources of risk and a stock of risk-free wealth. ${ }^{6}$ The economy consists of a series of state-contingent claims. Firms are uncertain about the states, but the claims are bundled together such that a firm must take

\footnotetext{
${ }^{5}$ We define hedging as risk reduction, but not necessarily total risk reduction. A firm may reduce only one type of risk and simultaneously increase another.

${ }^{6}$ An alternative assumption leading to the same results is that the firm has assets-in-place at time $\mathrm{t}=0$ which result from prior period operating, investment, and financing decisions. The expected payoffs to the assets vary through time.
} 
on both risks if it wants either. The firm is assumed to make its risk-management decision at time $\mathrm{t}=0$ after acquiring private information about the distributions of random payoffs to its assets-inplace. By definition, risk-management activities change the variation in payoffs to the firm's existing assets. Such activities include changing the composition of assets-in-place (on-balance sheet risk-management) as well as using derivative instruments to synthetically alter the expected payoffs to existing assets and liabilities (off-balance sheet risk-management).

Although risky assets owned by the firm may be traded, we assume the firm has an information advantage with respect to one of the sources of risk (compensated risk). This assumption implies that the firm earns economic rents from the asset and faces costs associated with liquidating the asset in the secondary market. Compensated risk is potentially diversifiable, however, diversification decisions simultaneously affect (either increase or decrease) all risks associated with the risky asset. Exchange-traded derivative instruments are not available to hedge the compensated risk since successful derivative contracts generally require a homogeneous underlying asset. ${ }^{7}$ Over-the-counter instruments are always available at a price, but the costs of over-the-counter instruments include a premium for liquidity and default risk. In addition, transactions costs are generally higher than those for exchange-traded instruments because of the costs associated with negotiation and customization. ${ }^{8}$

With respect to the second source of risk (hedgeable risk), the firm has neither an information advantage nor disadvantage. An example is any risk which results from a relatively homogeneous and not perfectly predictable source such as changes in commodity prices, interest rates, or exchange rates. This risk may be hedged (or increased) with exchange-traded derivative instruments. If the risky asset were divisible along the components of its total risk, the firm would

${ }^{7}$ Historical contract success (and failure) has indicated five characteristics of successful exchange-traded futures contracts: "1) A sizable pool of assets or income at risk; 2) The instrument underlying the futures contract is an accurate reflection of that risk; 3) The instrument underlying the futures contract is not subject to manipulation or distortion; 4) There must be a regular source of information about the instrument or index so that participants may trade knowledgeably; and 5) The successful futures market must meet the requirements of the different (market) participants more efficiently than do the competing markets." (Petzel, 1989, p. 3-4)

${ }^{8}$ Customization, though, may reduce the basis risk associated with over-the-counter instruments. 
not seek hedgeable risk and would choose only compensated risk. ${ }^{9}$ Assuming indivisibility, however, any decision which alters the firm's exposure to the compensated risk simultaneously affects the firm's exposure to the hedgeable risk.

A strategy which is not generally considered in the corporate risk management literature is for the firm to purchase more of the risky asset using the assumed available stock of risk-free wealth. This decision increases economic rents and hedgeable risk, and potentially increases compensated risk depending on the effects of diversification. Because derivative instruments are available to manage the hedgeable risk at low cost, however, the increase in hedgeable risk may be mitigated through synthetic hedging. The availability of derivative instruments effectively allows the firm to separate the choice about the returns to one source of risk exposure associated with a given investment from other risks which also result from the same investment. We denote the strategy of reducing hedgeable risk to allow for increases in compensated risk as Coordinated Risk Management. Within coordinated risk management, a firm attempting to increase total risk may optimally increase some risks while decreasing others. This coordination of risks is likewise predicted for a firm attempting to decrease total risk. In both cases, the firm will increase compensated risk, if any risk is to be increased, and decrease hedgeable risk.

Alternative strategies to change the combination of risks and returns of a portfolio have been considered in the corporate risk management literature. For example, the firm may sell the risky asset and invest the proceeds in a riskless asset. This strategy reduces both compensated and hedgeable risk as well as expected total return. Alternatively, the firm may diversify by selling less than 100 percent of the risky asset and investing the proceeds in another risky asset with less than perfect correlation in payoffs to the compensated risk. If hedgeable risk is unaffected by diversification, this strategy reduces only compensated risk but does not affect the portfolio's

\footnotetext{
${ }^{9}$ In practice we do not observe corner solutions representing elimination of hedgeable risk. One explanation is that total risk is not a constraint optimal risk allocation decisions. Another possibility is that the costs associated with fully hedging at all times are greater than the relative benefits.
} 
expected total return. Because the coordinated risk management strategy results in additional economic rents, this strategy dominates both of these alternative risk-management strategies. ${ }^{10}$

Concrete examples of the scenario envisioned are common. A mining company may earn economic rents by maintaining a comparative technical advantage which allows low-cost natural resource extraction or a comparative geological information advantage which allows the firm to choose viable potential sites. Acquiring mining rights, however, subjects the firm to price risk related to the natural resource. Similarly, a farmer may earn rents resulting from superior equipment maintenance, crop selection, or soil preparation. Acting on these compensated skills creates price risk associated with the crop.

\section{An Application to Financial Institutions}

\section{A. Interest-rate and credit risk}

Financial institutions provide a good opportunity to test for the implementation of coordinated risk management for at least three reasons. First, a single loan, either commercial or residential, financed by deposits or other debt, exposes the institution to two sources of risk: (i) interest-rate risk which represents unexpected changes in interest rates, and (ii) credit risk which represents unexpected changes in default arrival rates. Therefore, it is impossible to alter either risk in isolation by changing the institutions' assets-in-place. Second, interest-rate risk represents a hedgeable risk because derivative instruments with relatively low basis risk are available due to the fungible nature of the cost of money. Credit risk, by contrast, represents a compensated risk which is not easily synthetically hedged. Finally, good proxies are available to measure both interest-rate risk and credit risk quarterly as a result of regulatory reporting requirements.

\footnotetext{
${ }^{10}$ The coordinated risk management strategy dominates other strategies to the extent that the costs associated with this strategy are lower. Almost by construction, the costs of reducing hedgeable risks are less than the costs of managing compensated risks. Risk-management costs can be segregated into three types: transactions costs, opportunity costs and information costs. Transactions costs include fees for implementing a transaction such as brokerage fees and costs associated with margin requirements ("direct" transactions costs). Transactions costs also include indirect costs such as basis risk or costs associated with choosing a second-best investment because of constraints created by the indivisibility of assets. Opportunity costs represent the economic rents lost by a firm for not bearing compensated risk. Information costs result from an assumption of information asymmetry. Informed firms, earning economic rents, sell assets-in-place at a discount (or payoff liabilities at a premium) in equilibrium. This situation is commonly referred to as a lemons problem.
} 
We hypothesize that financial institutions coordinate the management of interest-rate risk and credit risk. Specifically, we predict that financial institutions optimally reduce interest-rate risk to exploit credit-risk opportunities. This prediction is consistent with Edwards (1981) who suggests that the costs of reducing credit risk include lost economic rents because financial institutions have a comparative advantage in making credit decisions over other firms. ${ }^{11}$ Financial institutions, however, do not necessarily have a comparative advantage in predicting interest rates and thus, do not receive rents for bearing this risk. In fact, Edwards argues that it is for this reason that derivatives markets, specifically futures and forwards, provide significant benefits to financial institutions. Diamond and Verrecchia (1982), in general, and Diamond (1984) and Campbell and Kracaw (1990), in particular, also observe that allowing interest-rate risk hedging is desirable for financial institutions. This conclusion is based on an assumption that freely observable information such as interest rate changes should be shared optimally.

The coordinated risk management hypothesis does not make predictions about total risk. Underlying the framework, however, is an institution's (potentially constrained) portfolio maximization problem resulting in an optimal level of total risk. Minimum regulatory capital requirements in the financial institutions industry constrain institutions' optimal level of total risk. These capital requirements constrain a thrift institution's ability to grow since the requirements must be met at the end of each quarter, not on average over the term of investment projects. Consequently, since capital ratios are computed as total regulatory capital relative to regulatory assets, ${ }^{12}$ increases in deposits as a source of funding for new investments without an immediate corresponding increase in regulatory capital, dilute the institution's capital position. An institution not meeting its minimum capital requirement potentially faces regulatory "taxes" including increased oversight, restrictions on operating activities, or, ultimately, closure.

"Credit derivative contracts became available in the early 1990s as a means of reducing or diversifying default risk. As of 1995, the credit derivatives market has grown to $\$ 2$ billion in notional value with credit default swaps being the most commonly used instrument. Financial institutions may use the instruments to reduce default risk associated with loans made for "...relationship purposes whether they make economic sense or not." (American Banker, September 26, 1995)

${ }^{12}$ After the Financial Institutions Reform, Recovery and Enforcement Act of 1989 (FIRREA), institutions were required to meet minimum capital requirements with respect to "tangible" capital/tangible assets (1.5\%); "core" capital/core assets (3\%); and "risk-based" capital/risk-weighted assets (8\%). 


\section{B. Risk Management Predictions}

We make predictions about risk-management for a sample of S\&Ls which convert from a mutual-charter to a stock-charter between 1984 and 1988. Although the coordinated risk management hypothesis applies to all firms in all industries, our sample has several advantages. First, the event of conversion provides a natural experiment to analyze changes in risk-management behavior related specifically to incentives which change as a result of conversion. In addition, restricting our sample to converting thrifts leaves us with a control sample of non-converting institutions. We use these institutions in both time-series and cross-sectional analyses to control for industry-wide factors affecting risk management decisions.

There are two consequences of the conversion process which potentially change the riskmanagement incentives of the converting thrift. First, the converting thrift's capital increases at the time of conversion by the amount of net issue proceeds. This new capital, and the future access to capital markets, effectively allows the institution to increase leverage and grow without violating capital constraints. ${ }^{13}$ Therefore, although the set of investment opportunities does not change as a result of conversion, the feasible set is larger post-conversion. ${ }^{14} \mathrm{By}$ contrast, non-converting thrifts do not have access to equity markets and, thus, are more constrained by minimum regulatory capital requirements. Established stock thrifts, unlike non-converting mutuals, may issue additional capital to fund growth. However, there are costs associated with seasoned equity offerings (SEOs)..$^{15}$ Hence, converting institutions have higher growth capacity than either nonconverting mutuals or established stock thrifts.

\footnotetext{
${ }^{13}$ This financial slack could be used by the management for increased perquisite consumption. However, Maksimovic and Unal (1993) provide evidence that the market prices the conversion as if management is not expected to inflate the financial slack at the expense of shareholders. Hence, the interests of management are aligned with those of shareholders.

${ }^{14}$ Typically conversion proceeds equal or exceed the book-value of equity of the mutual thrift. Assuming preconversion mutual equity meets regulatory capital requirements, doubling (at least) the capital ratio implies attaining borrowing capacity (effectively at the risk-free rate as a result of deposit insurance) which can also double the size of the thrift.

${ }^{15}$ In an SEO, the resolution of conflicts of interest between existing equityholders and new investors is costly (Asquith and Mullins, 1986; Masulis and Korwar 1986). As demonstrated by Myers and Majluf (1984), information asymmetries between existing equityholders and new investors can lead to underinvestment problems. For initial
} 
The second major consequence of conversion which accompanies the increase in capital adequacy is a change in ownership from the mutual depositors to both outside and inside stockholders. Prior to conversion, mutual thrifts are legally owned by depositors but not controlled by them. Rather, managers, compensated by a fixed salary, have control over the institution's net assets and act as the de facto owners. As Masulis (1987) and Rasmusen (1988) observe, such a fixed-wage contract can be viewed as risky debt since its value decreases as asset risk increases. Hence, mutual managers have incentives to choose lower-risk investment projects over riskier investments. Because the mutual institution's depositor-owners cannot control the thrift's assets, their risk preferences are irrelevant to the ultimate risk-taking behavior of the institution.

Upon conversion, management becomes accountable to risk-neutral shareholders who own and control the thrift. Unlike the depositor-owners of mutuals, shareholders are able to include stock and stock options in the managers' compensation contract, thereby better aligning the riskpreferences of the decision-making managers with their own. Consequently, conversion transfers de facto ownership from risk-averse managers to risk-neutral shareholders.

Taken together, the two affects of conversion imply that institutions optimally increase total firm risk following conversion and have the capital available to pursue a strategy of increasing risky assets. Our previous discussion suggests that this increase in total risk may be achieved by increasing credit risk exposure and decreasing interest-rate risk. We test these predictions by examining interest-rate risk and credit risk activities through time for converting thrifts, on average. ${ }^{16}$ Prior to conversion, we expect the sample institutions to resemble the non-converting mutuals with respect to interest-rate and credit risk. After conversion, we expect the institutions to follow a trend toward resembling their stock-chartered counterparts. We also analyze the coordination between interest-rate risk and credit risk within institutions through time and test cross-sectional differences in the extent of coordinated risk management by our sample institutions.

public offerings by converting thrift institutions, there are no "existing" shareholders, thus, the costs of obtaining capital through conversion are lower than in subsequent offerings.

${ }^{16}$ The fact that these risks are measured empirically in different "units" creates an obstacle for testing the net impact of changes in credit risk and interest-rate risk on total risk. 


\section{Sample Selection and Proxy Variables}

\section{A. Sample}

Mutual-to-stock conversions have been used to re-capitalize the thrift industry since the Garn-St Germain Act of 1982 which cleared legal barriers for regulatory approval of these transactions. ${ }^{17}$ From 1983 to 1988,571 conversions issuing stock totaling $\$ 10.1$ billion were completed, compared to only 130 mutual-to-stock conversions between 1975 and 1982.

Table I provides descriptive statistics about the thrift industry and its changing organizational structure during the 1980s. At the end of 1982, stock S\&Ls managed only 30 percent of the industry's assets, but by the end of 1988, stock S\&Ls controlled 74 percent of the industry's total assets. During the period 1982 to 1988, the S\&L industry's asset base doubled from $\$ 686$ billion to $\$ 1.4$ trillion while the asset base of Federal Deposit Insurance Corporation (FDIC) insured banks grew only 41 percent from $\$ 2.2$ trillion to $\$ 3.1$ trillion.

\section{[INSERT TABLE I HERE]}

Our sample consists of conversions completed between January 1, 1984 and December 31, 1988 according to the Office of Thrift Supervision. ${ }^{18}$ Of the 488 conversions during the sample period identified by Fleck (1990), 109 were supervisory conversions required by the Federal Home Loan Bank Board (FHLBB) or conversions that occurred simultaneously with a merger. Supervisory mergers and merger-conversions are excluded from the sample because we are unable to measure interest-rate risk and credit risk of the converting institution separate from that of its "purchaser" following conversion. The sample of converting institutions includes 348 institutions (of the 379 qualifying conversions) for which we can identify a docket (regulatory identification) number. ${ }^{19}$ We further restrict the institutions to those with total assets greater than $\$ 500$ million at

\footnotetext{
${ }^{17}$ In a comprehensive report on conversions, Williams, Fleck, and Comizio (1987) write: "The Bank Boards second major challenge, therefore, was to make conversions more accessible and attractive for acquirers of insolvent savings institutions. In that respect, every dollar of outside capital raised could be a dollar that the financially strapped Federal Savings and Loan Insurance Corporation ("FSLIC") would not have to expend." p. 238.

${ }^{18}$ The sample is restricted to this period because required data on interest-rate risk are not available from thrift regulatory reports prior to 1984 and reporting of interest-rate risk and other data changed significantly after March 1989. Additionally, FIRREA toughened thrift capital requirements and introduced both new regulations and new regulators which fundamentally changed the nature of the thrift regulatory environment.

${ }^{19} \mathrm{~A}$ docket number is unavailable if, subsequent to conversion, the institution changes its primary insurer to the FDIC or is closed by thrift regulators.
} 
each quarter end during the sample period. Controlling for size increases the likelihood of similarities across institutions with respect to their ability to access capital and derivatives markets (Gorton and Rosen, 1995) and their underlying production and cost functions (Carter and Stover, 1991). Institutions which are not FSLIC-insured are also excluded from the sample because of data availability. The final sample includes 81 converting institutions.

In addition to the sample of converting institutions, we use two control groups in our timeseries and cross-sectional tests to mitigate the effects of industry-related changes in risk-taking incentives during the sample period which are unrelated to thrift charter changes. For example, the "too-big-to-fail doctrine," which suggests a strategy of regulatory forbearance toward large institutions despite their capitalization, implies that depository institutions should optimally follow a high-growth strategy (O'Hara and Shaw, 1990). In addition, depository institutions, in general, have incentives to take on increased risk as it can be shifted to the government because of flat insurance premiums (Kane, 1985, 1989). To the extent that either of these risk-taking incentives, or others, were changing during the 1980s our control groups reduce their confounding effects on our results.

The first control group is established stock-chartered institutions. We identify 50 stockchartered institutions from CRSP and industry surveys that converted from mutual to stock charters no later than December 31, 1981. We impose this requirement to eliminate stock-chartered thrifts that are still experiencing post-conversion growth as of the start of the sample period. The second control group is non-converting mutual institutions. We obtain from thrift regulatory reports a sample of 1,565 institutions with mutual charters as of June 1989. After applying the criteria that size be greater than $\$ 500$ million at each quarter end during the sample period, the control samples include 36 stock-chartered institutions and 123 non-converting mutual institutions. Appendix I lists the names, cusip numbers and docket numbers of the 81 sample converting institutions and the 36 sample stock-chartered institutions.

\section{B. Proxies for Interest-Rate Risk and Credit Risk}


All proxy variables are measured quarterly for each institution using data obtained from call reports filed with the FHLBB, predecessor to the Office of Thrift Supervision (OTS). The data are self-reported to regulators and unaudited. We measure on-balance sheet interest-rate exposure using an institution's one-year maturity gap, or the excess of interest-rate sensitive assets over interest-rate sensitive liabilities maturing within one year, scaled by total assets (GAP/TA) ${ }^{20} \mathrm{We}$ assume that an institution with a perfectly matched gap (GAP/TA equals zero) is exposed to less interest-rate risk than an institution with either a negative or positive one-year maturity gap. The one-year maturity-gap measure represents only the short-term, cash-flow mismatch of the institution and ignores the distribution of contractual maturities greater than one-year. ${ }^{21}$

In addition to managing interest-rate risk through restructuring of on-balance sheet assets and liabilities as reflected in gap, a thrift may alter its interest-rate exposure synthetically using derivative instruments. ${ }^{22}$ Derivatives, unlike on-balance sheet instruments, affect only the interestrate exposure of the institution, and thus, eliminate problems associated with intermingling interestrate and credit-risk decisions. ${ }^{23}$ Additionally, derivatives provide institutions with a relatively lowcost alternative for actively managing nonlinear, dynamic interest-rate exposure.

Institutions separately report the effects of derivatives use on each maturity gap in Section $\mathrm{H}$ of their quarterly regulatory reports under the heading, "Impact of Hedging Activities." Since these off-balance sheet activities are not net assets of the firm, but rather only change the maturity composition of existing assets and liabilities, the reported impact of derivatives on GAP sums to

\footnotetext{
${ }^{20}$ Thrifts report their gap for various maturity categories including zero-to-three months, three-to-six months, six months-to-one year, one-to-three years, three-to-five years, five-to-ten years, ten-to-twenty years, and greater than twenty years. The remaining time to maturity of an interest-rate sensitive asset or liability as defined by the FHLBB is based on the contractual maturity of the instrument. Embedded options are not considered. In particular, thrifts include adjustable-rate mortgages in the maturity category reflecting the period from the reporting date to the date of the next adjustment. We include passbook and NOW account balances in the one-year maturity category.

${ }^{21} \mathrm{We}$ recognize that duration gap (the difference between the durations of the institution's assets and liabilities) which considers the entire distribution of cash flows is a better measure of an institution's on-balance sheet interestrate risk (Bierwag and Kaufman, 1985). However, an institution's duration gap is not publicly available. Duration gap can be estimated using maturity gap data but previous attempts have not provided a successful method of estimation. (See, for example, Bennett, Lundstrom and Simonson, 1986.)

${ }^{22}$ As of the early 1980 s, institutions were allowed to use futures, options, swaps, and other derivative instruments to reduce interest-rate risk subject to certain regulatory restrictions (see CME White Paper, 1987).

${ }^{23} 0$ ver-the-counter derivative instruments create counterparty default risk while credit risk related to exchangetraded instruments results only from the possibility of exchange failure. We do not consider swap counterparty default risk to have the same credit risk implications for an institution as the risk associated with real estate.
} 
zero across all gap maturity categories. ${ }^{24}$ The calculation of the impact is consistent across all institutions following guidelines set forth by the FHLBB. (A summary of the rules for computing the impact of hedging activities on gap is included in Appendix II.) An institution's net one-year gap after adding back (or subtracting) the "impact" of derivatives (scaled by total assets) is denoted as NET/TA.

Previous research provides evidence that short-term maturity gap is related to the market's assessment of financial institutions' exposure to unexpected changes in interest rates (Flannery and James, 1984; Pilloff, 1994; Schrand, 1994b). To test the robustness of these results for our sample institutions, we measure the association between one-year maturity gap, net of the impact of derivatives (NET/TA), and market interest rate sensitivity in Appendix III. The results suggest that our measure of interest-rate sensitivity (NET/TA) is a good proxy for the interest-rate beta of our sample institutions estimated using a two-factor market model.

We measure quarterly changes in credit risk for converting institutions using the ratio of real estate held for investment to total assets (REALE). Real estate held for investment, which excludes real estate owned after foreclosure or real estate held during foreclosure proceedings (commonly referred to as REO and REH), generally exhibit a higher default risk than mortgagerelated assets (Cordell, MacDonald, and Wohar, 1993). Therefore, increases in holdings of real estate following conversion are predicted to proxy for increases in credit risk exposure. All variables are scaled by total assets rather than total equity because of the significant impact of conversion on total equity.

\section{[INSERT TABLE II HERE]}

Table II provides yearly mean size and capitalization values for our conversion sample (in the quarter immediately prior to conversion) and the two control groups during the period 1984 to

\footnotetext{
${ }^{24}$ For example, an institution may report that the impact of "hedging" on the $0-12$ month maturity category is positive $\$ 100$ million offset by an impact of negative $\$ 100$ million in the 5-10 year maturity category. In this example, the institution is effectively using derivatives to convert assets which mature in as many as ten years into assets with an effective maturity of less than twelve months (or liabilities which mature in as few as twelve months into liabilities with an effective maturity of ten years).
} 
1988. ${ }^{25}$ In addition, the average values for the proxy variables for interest-rate risk (GAP/TA, NET/TA) and credit risk (REALE) are given. Both interest-rate risk and credit risk exhibit timeseries variation. We control for this in our time-series tests using the sample of established stock thrifts (see Section IV). The means indicate significant differences in the asset sizes of the three samples. Even after excluding institutions with total assets (TA) less than $\$ 500$ million, stock institutions are larger and non-converting mutuals are smaller, on average, than the converting institutions. Tangible net worth ratios (CAPITAL) also differ across the three samples. The converting institutions are better capitalized than either the non-converting mutuals or the established stock institutions.

Figure 1 shows the time-series behavior of the quarterly means for each variable from eight quarters before to twelve quarters after conversion for the converting sample. While the average capital ratio reflects the proceeds from conversion at time $t$, it decreases following conversion in accordance with the observed increase in total assets. In addition, interest-rate risk appears to decrease following conversion as a result of both on-balance sheet (GAP/TA) and off-balance sheet (NET/TA) activities while credit risk proves to be increasing slowly.

\section{[INSERT FIGURE 1 HERE]}

Table III presents the mean for each interest-rate risk and credit risk variable for the converting sample and the two control groups over the 1984 to 1988 period. Results for the 81 converting institutions are divided into pre-conversion and post-conversion quarters. Panel A of Table III indicates that the quarterly percentage increase in total assets (GROWTH) for the converting sample increases significantly post-conversion, approaching the average growth levels of established stock institutions. In particular, converting institutions increase their growth rate of total assets from 2.5 percent per quarter prior to conversion to 3.2 percent after conversion. This compares to growth rates of 1.7 percent for non-converting mutuals and 3.5 percent for stock institutions.

\footnotetext{
${ }^{25}$ In some cases, data for the quarter immediately preceding the conversion quarter are not available. In those cases, the last quarter prior to conversion is used.
} 
Panel B of Table III shows that converting institutions decrease their exposure to interestrate risk significantly from the pre-conversion period to the post-conversion period. Prior to conversion, the converting institutions are similar to non-converting mutuals with respect to the management of interest-rate risk. During, the post-conversion period, however, these institutions decreased their interest-rate risk to levels, on average, lower than those of stock-chartered institutions. Both pre and post-conversion, the frequency of the use of derivatives (\% users) by converting institutions is greater than that of non-converting institutions (significant only postconversion) and less than that of the stock sample. Considering the growth in size achievable as a result of conversion, these results are consistent with prior research which has found that larger institutions are significantly more likely to use derivative instruments (Nance, Smith and Smithson, 1994; Sinkey and Carter, 1994).

\section{[INSERT TABLE III HERE]}

With respect to credit risk (Panel C of Table III), the differences among the three samples also suggest that the converting institutions follow a trend of changing their risk exposure following conversion to resemble that of stock-chartered institutions. The average holdings of real estate investments are 0.1 percent, on average, post-conversion compared to 0.04 percent preconversion. This change, however, is not statistically significant.

\section{Methodology and Results}

The results presented in Figure 1 and Table III provide descriptive evidence that converting institutions change their risk-taking behavior after conversion consistent with the predictions of the coordinated risk management hypothesis. This section provides more explicit tests of the source, timing and degree of these changes.

\section{A. Time-Series Behavior of Risk Management at Converting Thrifts}

In general, our approach is to estimate ordinary least squares (OLS) regressions relating proxies for risk to indicator variables marking the position of the observation quarter relative to the 
event (conversion) quarter. Define Time $(t+k)$ as an indicator variable equal to 1 if the quarter $t$ is $\mathrm{k}$ quarters before or after the conversion quarter, where $\mathrm{k}$ ranges from -9 to +12 ; otherwise Time $(\mathrm{t}$ $+\mathrm{k})=0 .{ }^{26}$ The observation for institution $\mathrm{j}$ at Time $(\mathrm{t}+0)$ represents the thrift's risk exposure as of the end of the quarterly reporting period during which the conversion is completed. Data are not available to measure GAP/TA, NET/TA and REALE for all converting institutions across all time variables since the sample period is restricted to 1984 through 1988. For example, institutions converting during the quarter ended December 1984 have data available beginning only at Time(t3) or March 1984. At the other extreme, data for institutions converting during the quarter ended June 1988, for example, are available only through Time $(t+2)$ or December 1988.

Specifically, we regress proxy variables for exposure to both interest-rate risk and credit risk (RISK) for each institution $\mathrm{j}$ for each quarter $\mathrm{t}$ from March 1984 through December 1988 on the time indicator variables as follows:

$$
\operatorname{RISK}_{\mathrm{jt}}=\alpha+\sum_{\mathrm{k}=-9}^{12} \beta_{\mathrm{k}} \operatorname{Time}(\mathrm{t}+\mathrm{k})+\sum_{\mathrm{r}=1}^{5} \delta_{\mathrm{k}} \operatorname{Region}_{\mathrm{r}}+\mathrm{e}_{\mathrm{jt}} .
$$

In addition to the time variables, we include indicator variables (Region ${ }_{\mathrm{r}}$ ) which control for potential differences across geographic regions related to real-estate market conditions, growth opportunities, and regulatory oversight. The five regions ( $r=1$ to 5) defined by the Resolution Trust Corporation are: Northeast, Southeast, Central, Southwest, and West. ${ }^{27}$

Pooling the observations over a five-year period (1984-1988) enables us to examine the trends in risk-taking behavior on a relatively large sample. To mitigate the potential impact of

\footnotetext{
${ }^{26}$ Indicator variables are only included for the relative event quarters -9 to +12 because the other quarters have less than 30 observations.

${ }^{27}$ States within the regions are classified as follows:

Northeast: Connecticut, Delaware, Maine, Maryland, Massachusetts, New Hampshire, New Jersey, New York, Ohio, Pennsylvania, Rhode Island, Vermont, Washington D.C.

Southeast: Alabama, Florida, Georgia, Kentucky, Louisiana, Mississippi, North Carolina, Puerto Rico, South

Carolina, Tennessee, Virginia, West Virginia

Central: Arkansas, Illinois, Indiana, Iowa, Kansas, Michigan, Minnesota, Missouri, Nebraska, North Dakota, South Dakota, Wisconsin Southwest: Oklahoma and Texas

West: Alaska, Arizona, California, Colorado, Hawaii, Idaho, Montana, Nevada, New Mexico, Oregon, Utah,

Washington, Wyoming
} 
confounding events on the results, we measure both interest-rate risk and credit risk of the converting institutions relative to the control sample of stock-chartered institutions. Specifically, for each converting institution $j$ for each quarter $t$, we calculate the excess of GAP/TA $A_{j}, N E T / T A_{j}$, and $\mathrm{REALE}_{\mathrm{j} t}$ over the mean of the corresponding variable for the control group for the same calendar quarter $t$ to create three new variables: XSGAP, XSNET, and XSREALE, respectively. These excess (XS) measures are used as the dependent variables to estimate equation (1). Because stock-chartered and converting institutions are exposed to the same exogenous industry factors, these standardized dependent variables reduce the effects of time-series variation in risk-taking behavior unrelated to conversion on our results.

\section{[INSERT TABLE IV HERE]}

Table IV presents the results related to the time-series behavior of the management of interest-rate risk and credit risk after controlling for regional differences in exposure ${ }^{28}$ Columns 1 and 2 show results for XSGAP and XSNET, respectively. In both cases, the estimated intercept is negative and significant. Note that, on average, both the conversion sample and the control sample have liabilities maturing in one year exceeding assets maturing in one year (negative GAP/TA and NET/TA values). Hence, the negative intercepts related to excess GAP/TA and NET/TA imply that the control group of stock institutions has significantly less interest-rate risk than the converting thrifts. This observation is consistent with Schrand (1994a) who reports that stock institutions have less interest-rate exposure than mutual-chartered institutions.

During the pre-conversion period, changes in risk exposure between the two groups are not significant. Following conversion, however, interest-rate risk is reduced using both on-balance sheet and derivative instruments. The gap positions of converting institutions gradually become similar to those of stock institutions (XSGAP) over approximately nine quarters following conversion as evidenced by the sum of the intercept of -0.0702 and the coefficient on quarter $t+9$ of 0.0642. By contrast, as reflected in XSNET, immediate use of derivative instruments by converting institutions makes their net gap positions similar to those of stock institutions after only

\footnotetext{
${ }^{28}$ Only 64 of the 81 converting institutions have data available at time t. Using only these 64 institutions as the sample, the results presented in Tables III and IV are qualitatively similar.
} 
five quarters (mean XSNET of -0.0659 plus conditional effect in quarter $t+5$ of 0.0664 ). Hence, the net interest-rate risk of the converting institutions improves faster than that associated with only on-balance sheet instruments.

Results related to the management of credit risk are presented in the last column of Table IV. The negative intercept indicates that the control sample of stock institutions have, on average, a greater investment in real estate as a percent of their assets than converting institutions, suggesting that stock, institutions are exposed to higher credit risk. However, we observe the credit-risk exposure of converting institutions relative to that of the stock-chartered sample significantly increasing beginning three quarters after conversion. The change in credit-risk exposure is slower than that of interest-rate exposure, however, being reduced by only 15 percent nine quarters after conversion (conditional effect in quarter $t+9$ of 0.0018 relative to mean XSREALE of -0.0117 ). These results are consistent with prior empirical evidence documenting an increase in credit risk associated with asset portfolios following conversion (Hadaway and Hadaway, 1981; Verbrugge and Goldstein, 1981; Simons, 1992; Cordell, MacDonald and Wohar 1993).

Although the results are not presented, we also perform these time-series tests using nonconverting mutual institutions as a control group. The results are qualitatively similar in that the converting institutions exhibit a trend toward decreasing their interest-rate risk exposure in the post-conversion period. The intercepts in these regressions are positive but not statistically different from zero. This result indicates that, on average, the converting institutions were similar to the non-converting thrifts prior to conversion with respect to interest-rate risk. Conversion, however, is associated with increased interest-rate risk management.

These observations only indicate that, on average, interest-rate risk across all institutions decreases following conversion while credit risk increases. The coordinated risk management approach, however, predicts that interest-rate risk decreases are associated with increases in credit risk following conversion within each institution. To specifically test the predictions of the coordinated risk management approach within thrift institutions, we estimate the following pooled 
regressions from nine quarters before to twelve quarters following conversion (White-corrected tstatistics in parentheses):

$$
\text { XSNET }_{j \mathrm{t}}=0.05+3.77 \mathrm{XSREALE}_{\mathrm{jt}}+\mathrm{e}_{1 \mathrm{jt}}, \quad \quad \text { Adjusted } \mathrm{R}^{2}=1.6 \%
$$

$$
\operatorname{XSGAP}_{\mathrm{jt}}=0.03+2.76 \mathrm{XSREALE}_{\mathrm{jt}}+\mathrm{e}_{2 \mathrm{jt}} \text {, and } \quad \text { Adjusted } \mathrm{R}^{2}=0.1 \%
$$

$$
\begin{aligned}
\mathrm{XSNET}_{\mathrm{jt}}= & 0.02+0.87 \mathrm{XSGAP}_{\mathrm{jt}}+1.36 \mathrm{XSREALE}_{\mathrm{jt}}+\mathrm{e}_{3 \mathrm{jt}} \cdot \quad \text { Adjusted } \mathrm{R}^{2}=78.1 \% \\
& (4.6)(62.0)
\end{aligned}
$$

Using XSNET as a measure of interest-rate risk in equation (2) allows us to examine the overall coordination of an institution's net interest-rate risk (considering both on and off-balance sheet hedging) and credit risk. We further examine whether the coordination of risk-management activities is achieved through the use of on-balance sheet instruments, using XSGAP as the regressand in equation (3), or derivatives, using XSNET as the regressand in equation (4) conditional on XSGAP. To interpret the coefficient estimates, it should be noted that the closer an institution's maturity gap is to zero relative to that of the sample of stock institutions, the better hedged is its balance sheet with respect to interest-rate risk. Hence, higher XSGAP (less negative) reflects greater on-balance sheet hedging activity while higher XSNET (less negative), controlling for XSGAP, reflects greater off-balance sheet hedging.

The positive coefficients on XSREALE in equations (2) through (4) indicate that increases in credit risk for a given institution over time, relative to the control sample of stock institutions, are significantly associated with both on and off-balance sheet hedging of interest-rate risk, respectively. In addition, the coefficient estimate on XSGAP in equation (4) is statistically significantly less than unity which suggests that on average derivatives use is significant and that derivatives are used to reduce, or hedge, institutions' net interest-rate risk. The results are 
qualitatively similar controlling for size. These results support the coordinated approach to risk management which predicts that thrifts reduce their interest-rate risk exposure while simultaneously taking on increasing levels of credit risk.

\section{B. Cross-Sectional Determinants of Risk Management at Converting Thrifts}

Following Froot, Scharfstein and Stein (1993) and Smith and Stulz (1985), the coordination between interest-rate risk hedging and credit risk taking can be related to growth opportunities and managerial compensation. Froot, Scharfstein and Stein (1993) show that variation in internal wealth between time $\mathrm{t}=0$ and time $\mathrm{t}=1$ is costly to firms because a low outcome at time $\mathrm{t}=1$ may result in underinvestment. Consequently, the greater a firms growth potential, the greater are the expected costs associated with variation in cash flows. Thus, the magnitude of an institution's intended growth following conversion is predicted to be positively associated with its degree of interest-rate risk reduction. An underlying assumption of their model is that external financing is more costly than internal financing because of information asymmetry and agency costs. Particularly in the savings and loan setting, the assumption that external financing costs exceed internal financing costs is reasonable because of financing constraints which result from minimum capital requirements.

We use an ex ante proxy for the level of attainable growth following Maksimovic and Unal (1993). Calculation of this proxy requires an understanding of the conversion and appraisal processes. ${ }^{29}$ Prior to conversion, an independent appraiser determines the number of shares to be issued and a range of offer prices with minimum and maximum prices set at fifteen percent below and above a mid-price. Depositors have priority to purchase shares subject to a limit based on the level of his or her deposits. The depositor must pay the maximum appraisal price per share for each subscribed share at the time of the subscription. Depending on demand, market conditions, and management's incentives, management chooses an offer price within the appraisal range. Management can affect the issue size within the range given by the appraiser. However, the

\footnotetext{
${ }^{29}$ For an excellent description of the sale-of-stock approach see Williams, Fleck, and Comizio (1987).
} 
manager faces a trade-off between reducing the issue size, thereby maximizing the after-market returns, and increasing the issue size, thereby raising additional funds for expansion. ${ }^{30}$ Given the chosen offer price, shares are then issued first to managers and then to depositors. If there is insufficient demand, the remaining shares are offered first at the set price to depositors which purchased their maximum allowable shares. Any remaining shares are offered to the public. If there is excess depositor demand, the actual shares available for depositors are rationed. Any funds collected from depositors which exceed the final purchase price are returned.

Ex ante growth opportunities are measured by the chosen issue price of the converting thrift relative to the midpoint of the appraisal range, denoted as THETA. The closer the value of the offer price to the upper limit of the appraisal range (the higher the THETA), the greater is the financial slack created at the time of conversion. ${ }^{31}$ To the extent this growth represents management's expectation of its intentions to exploit deposit insurance subsidies, the coordinated risk management framework predicts that THETA is positively related to increases in credit risk and increased hedging of interest-rate risk following conversion.

Another set of cross-sectional predictions about the optimal risk-taking behavior of manager-agents comes from Smith and Stulz (1985). In their model, managers are assumed to be risk-averse with indirect utility functions of wealth which are strictly concave. A manager's wealth consists of both pecuniary compensation and the payoff of his or her non-tradable investment in the firm. Based on these assumptions, Smith and Stulz predict that greater managerial share holdings will increase incentives for managers to hedge cash flow or profit variation, while nonlinear compensation packages (with option-like features) may be associated with greater risktaking. ${ }^{32}$ Although this prediction applies to all financial institutions, and not just converting

\footnotetext{
${ }^{30}$ Maksimovic and Unal (1993) analyze the factors affecting the choice of the issue size within the appraisal range. They provide evidence that this reflects the alignment between management and initial shareholder interests.

${ }^{31}$ Maksimovic and Unal (1993) provide evidence that share-price run-up on the first day of trading following conversion is positively and significantly associated with THETA. This result is consistent with the market attaching value to the creation of financial slack. Furthermore, they provide evidence that ex post growth rates are significantly correlated with THETA.

${ }^{32} \mathrm{We}$ recognize that an alternative for the manager is to hedge his or her investment outside of the firm. However, there are practical limitations to implementing such a strategy. For example, managers may not take short positions in the firm's stock because of high transactions costs (due to illiquidity) or SEC or regulatory prohibitions on short sales.
} 
thrifts, shares and/or options become available to compensate thrift managers only following conversion. As a result, we predict that post-conversion hedging of interest-rate risk and coordination of risks is positively associated with share-ownership attained at the time of conversion. Managerial compensation consisting of options, rather than shares, provides contrasting cross-sectional predictions about optimal risk-taking. Smith and Stulz (1985) suggest that options provide managers with incentives for greater risk-taking. This implies that thrifts with higher option holdings may hedge interest-rate risk less. ${ }^{33}$

Converting institutions report the components of managerial compensation, including share purchases and options granted, in offering prospectuses. We use the total value of shares purchased by management at the time of conversion, expressed as a percentage of the conversion proceeds (INSIDE), to proxy for the management's ownership of the thrift. Option holdings by management (OPTS) are measured as the ratio of the number of options granted to management at conversion relative to the total number of shares issued at conversion. Data to calculate THETA, INSIDE and OPTS are obtained from Maksimovic and Unal (1993).

\section{[INSERT TABLE V HERE]}

Table $\mathrm{V}$ provides descriptive statistics of these variables. The average choice of THETA is approximately one standard deviation less than unity with many firms choosing either close to the minimum price ( 85 percent of the midpoint), close to the maximum price (115 percent of the midpoint), or the midpoint (1.00). The distribution of managerial shareholdings is skewed toward zero with 4.6 percent of shares held by managers as a group, on average. Approximately one-half of the sample firms have no executive stock options. For those institutions which do employ stock options as a component of managerial compensation, the percentage of options granted at

\footnotetext{
${ }^{33}$ In addition to holding a call option on the value of his or her levered institution, a thrift manager also holds a put option on the institution written by the government in the form of deposit insurance. Consequently, a manager's net position with respect to the firm resulting from share ownership and this government guarantee is a long call with a strike price at the institution's debt level and a long put with a strike price at the debt level at which the regulators will liquidate the institution. If regulators exhibit forbearance allowing institutions to remain in operation despite technical insolvency, the net position on the underlying institution resembles a long strangle (the strike price of the long call exceeds that of the long put). In this case, a manager of an institution near insolvency is long volatility and has incentives to speculate much greater than those of a manager holding only a call without the put option.
} 
conversion relative to the number of shares issued is generally less than 10 percent, however, one firm provided its managers with options to buy shares representing 19.2 percent of the total shares issued.

Results of the first series of cross-sectional tests are presented in Tables VIa and VIb. These tests repeat the time-series analysis of average changes in interest-rate risk and credit risk for partitions of the sample firms based on THETA, INSIDE, and OPTS. To test the cross-sectional association of interest-rate risk and credit risk with the level of ex ante growth opportunities, we estimate equation (1) separately for firms with THETA $\geq 1$ (high-THETA) and THETA $<1$ (lowTHETA). Columns (1) through (4) report the contrasting results for high and low-THETA firms. For both the low and high-THETA samples, the negative intercept estimates show that converting thrifts have significantly greater net interest-rate exposure and less credit exposure than the sample of stock-chartered institutions, on average. Beginning approximately one year prior to conversion, however, the results in Column (1) indicate that the high-THETA institutions become increasingly better managed with respect to interest-rate risk, reducing their net exposure by approximately twelve to twenty percent, on average, across the post-conversion period. The low-THETA institutions also increase their hedging activities related to interest-rate risk, however, the improvement in XSNET is approximately one-third to one-quarter that achieved by the highTHETA institutions. In addition, the low-THETA institutions do not begin managing their interest-rate risk until four quarters following conversion.

With respect to the concurrent management of credit risk, both low and high-THETA thrifts maintain a smaller investment in real estate, on average, than the control sample of stock-chartered institutions prior to conversion. High-THETA institutions increase their investment in real estate within the first two years following conversion, decreasing the average differential with stockchartered firms by approximately fifty percent $(0.0058 /-0.0128)$. The low-THETA firms, however, do not show a significant increase in credit risk. In fact, these institutions decrease their credit risk exposure immediately following conversion. In summary, these results are consistent 
with the predictions of coordinated risk management that high-growth firms simultaneously decrease hedgeable risk while attaining their growth in compensated risk.

\section{[INSERT TABLE VIa HERE]}

Growth opportunities as measured by THETA are only a potentially important determinant of the manager's incentives with respect to risk-taking if the manager benefits from increases in firm value through compensation such as share ownership. ${ }^{34}$ The association between managerial share holdings and interest-rate and credit risk is estimated for two equal-sized partitions of the sample of converting thrifts (high share ownership and low share ownership) based on management's holdings (see Columns (5) through (8) of Table VIa). The results indicate that managerial share purchases are positively related to post-conversion reduction in exposure to interest-rate risk. As Columns (5) and (6) show, managers of those institutions which purchased less than the median percentage of shares reduce the institution's exposure to interest-rate risk but not as significantly as managers with high share ownership. In fact, the high-share managers begin to significantly improve the interest-rate risk exposure of their institutions four quarters prior to the conversion quarter. These institutions exhibit significantly better interest-rate risk management than the low-share-ownership thrifts as early as seven quarters prior to conversion. One possible explanation for the increased interest-rate risk management prior to conversion is that managers intending greater share purchases at conversion view interest-rate risk management as a value maximizing activity. More of this increase in value will accrue to managers intending high share purchases at conversion because a mutual thrift's value becomes a windfall profit to the initial shareholders of a converting institution. ${ }^{35}$

Simultaneous with these patterns in interest-rate risk management, Columns (7) and (8) show that institutions whose managers have the lowest insider share holdings do not increase their credit risk as significantly as institutions with high managerial share ownership. These findings are consistent with Maksimovic and Unal (1993) who report that managerial share purchases are

\footnotetext{
${ }^{34}$ An institution's compensation structure both before and after conversion is a choice variable like interest-rate risk or credit risk. Although there are some regulatory restrictions on managerial share purchases, flexibility remains. The endogeneity of compensation structure and incentives for risk-taking is discussed in Tufano (1995).

${ }^{35}$ Unal (1995) describes how windfall profits accrue to initial shareholders of converting thrifts.
} 
greater for more valuable thrifts and, moreover, that such conversions experience greater aftermarket stock price appreciation.

\section{[INSERT TABLE VIb HERE]}

In addition to the share-component of managerial compensation, we consider the relation between executive stock options and interest-rate risk and credit risk for the sample firms partitioned into three groups based on their level of option holdings. One group represents institutions whose managers hold no options. The remaining institutions are divided into two groups of equal size, high and low, which consist of institutions with option holdings greater than and less than the median holdings, respectively. The results provide a contrasting view to that presented based on the association between share holdings and risk-management. Columns (1) and (2) of Table VIb show that institutions whose managers hold zero or low levels of options significantly reduce their interest-rate risk after conversion relative to the control group. In contrast, for thrifts whose managers have high option holdings we observe a significant reduction in interest-rate risk in only two quarters following conversion. In other words, the institutions with high option holdings are the least likely to attempt to manage their interest-rate risk exposure. This observation is consistent with the predictions of Smith and Stulz (1985) that options create convexity in a manager's incentives with respect to risk.

Concurrent with their interest-rate risk management, the institutions with no or low option holdings invest more in risky real estate following conversion. The institutions with high option holdings, by contrast, are not significantly increasing their holdings of risky real estate. However, managers choosing high options, on average, manage institutions that are significantly more risky with respect to credit risk than managers that choose zero or low levels of options as evidenced by the intercepts in Columns (4) through (6). The support for this observation is quite weak, though, because of the small sample size and lack of explanatory power for the high-option thrifts in Column (6).

The results of Tables VIa and VIb, although informative about trends in both interest-rate risk and credit risk, do not show the relation between the two within an institution. We estimate 
equations (2) through (4), which relate interest-rate risk to credit risk for the panel data, separately for partitions of each of the variables predicted to be cross-sectional determinants of risk-taking behavior: THETA, INSIDE, and OPTS. We estimate these regressions using White's (1980) correction for the standard errors because the estimations exhibit heteroskedasticity. Indicator variables are used to separately estimate the association between interest-rate risk and credit risk in the pre and post-conversion periods. The results are reported in Table VII.

\section{[INSERT TABLE VII HERE]}

Panel A shows that the high-THETA firms show a significant and positive association between net interest-rate risk (XSNET) and credit risk post-conversion. We observe a similar relation between on-balance sheet interest-rate risk (XSGAP) and credit risk. Recall that a positive association suggests that the higher an institution's exposure to credit risk, the closer to zero (less negative) is its maturity gap or the lower is its interest-rate risk. Hence, for high-THETA thrifts, increasing credit risk is significantly associated with greater interest-rate risk hedging following conversion. Estimation of the XSNET equation, controlling for XSGAP, shows a significant positive association between net interest-rate risk and credit risk only in the pre-conversion period for the high-THETA sample. This implies that, during the pre-conversion period, the association between net interest-rate risk and credit risk is driven by the institutions' on-balance sheet interestrate exposure rather than derivatives use. The low-THETA firms also show a significant positive relation between on balance sheet interest-rate-risk hedging and credit risk-taking only in the preconversion period. In contrast to the high-THETA firms, the low-THETA thrifts do not exhibit any significant association between interest-rate risk hedging and credit-risk taking. Also, the estimation of equation (4) for the low-THETA firms indicates that derivatives use increases following conversion as evidenced by the decrease in the coefficient on XSGAP from 0.936 to 0.844. Also, as shown by the continued positive and significant coefficient on XSREALE in the post-conversion period, this increased derivatives use is associated with relative increases in credit risk. In summary, we observe that coordination of interest-rate risk and credit risk is more pronounced post-conversion for thrifts which attain high growth capacity at the time of conversion. 
Panel B of Table VII shows the association between interest-rate risk and credit risk for firms with low and high managerial share ownership. For managers with high levels of share ownership, the results indicate that the coordination of interest-rate risk and credit risk is significant and positive only in the post-conversion period. By contrast, for managers with low levels of share ownership, the results indicate no significant association between interest-rate risk and credit risk post-conversion. With respect to interest-rate risk management alone, as in Panel A, three of the four coefficient estimates on XSGAP are significantly less than unity implying that derivatives use, on average, reduces interest-rate risk. The use of derivatives for managers with both high and low levels of share ownership increases following conversion.

Panel C of Table VII reports results for the three partitions of firms based on their managerial option holdings. Estimation of equations (2) and (3) show that the relation between net interest-rate risk and credit risk is positive and significant for institutions whose managers have high option holdings post-conversion. By contrast, for institutions whose managers hold low options, the association is negative and significant post-conversion and for institutions whose managers hold no options, the association is positive and significant but only in the pre-conversion period.

The results also demonstrate that option holdings not only affect the coordination of riskmanagement activities, but also the choice between on or off-balance sheet instruments to achieve interest-rate risk reduction. Specifically, the trend of coordinating risk-management for the highoption institutions is dominated by their use of derivatives to manage interest-rate risk. Estimation of equation (4) shows an extensive use of derivatives based on the coefficient estimates on XSGAP of 0.827 and 0.638 , respectively, pre and post-conversion. The difference between these estimates and unity represents the extent of on-balance sheet risk which is reduced as a result of derivatives use. This greater use of derivatives to manage net interest-rate risk in the high-option group may seem inconsistent with the predictions of Smith and Stulz (1985). However, the increased use of derivatives is combined with more risky on-balance sheet positions for the highoption managers. Calculating the mean XSGAP for the high, low and no-option groups in the 
post-conversion period, we find that on-balance sheet interest-rate risk is highest for the highoption group with a mean XSGAP of -0.008. By comparison, the mean XSGAP positions for the low and no-option groups, respectively, are 0.033 and 0.015 .

This relatively high on-balance sheet interest-rate risk for the high-option institutions combined with the extensive use of derivatives to manage this risk suggests that managerial option holdings affect the manner in which interest-rate risk is managed but not the level of net interestrate risk. Thrifts with greater managerial option holdings achieve their interest-rate risk hedging through the use of derivative instruments rather than on-balance sheet asset/liability matching. This behavior is consistent with the conjecture that the relative liquidity of derivatives offers thrifts the opportunity to selectively manage their interest-rate exposure based on their expectations of interest-rate changes. In other words, these institutions hold the "option" to become high-risk as a result of their risky gap positions simply by liquidating their derivatives positions. Since speculation with derivatives is prohibited, maintaining a more negative gap position is the only way for institutions to speculate on interest rates.

\section{Conclusion}

This paper proposes an approach to analyzing risk management activities when multiple risks are bundled within a firm's assets or liabilities. We classify potentially bundled risks into two types: compensated risk and hedgeable risk. Firms earn rents for bearing compensated risk such as credit risk and earn zero economic rents for bearing hedgeable risk such as interest-rate risk. Because the costs associated with reducing hedgeable risk are lower than those associated with compensated risk, firms rationally eliminate hedgeable risks using either on or off-balance sheet strategies. Thus, hedging becomes desirable even for risk-neutral or risk-seeking firms as a means of allocating risk. We denote this approach of optimal risk allocation among multiple risks within a firm as Coordinated Risk Management.

We test the coordinated risk management approach by examining the interaction between interest-rate risk (hedgeable risk) and credit risk (compensated risk) management at thrift 
institutions following conversion from a mutual-to-stock form of ownership. Although the concept of coordinated risk management applies to any firm, we use this sample because of data availability for the sample of converting thrifts and the control groups of non-converting institutions. The time-series findings are consistent with the coordinated management of interestrate risk and credit risk. In particular, immediately at conversion we observe decreased interestrate risk across institutions combined with a more gradual trend toward increasing credit risk. The negative relation between interest-rate risk and credit risk is also significant in pooled tests. In addition, institutions use both on-balance sheet strategies and derivative instruments to reduce interest-rate risk. This finding of decreasing interest-rate risk occurs despite incentives to increase total risk following conversion. In light of the current discussions on the use of derivatives, this finding also indicates that thrifts use derivatives instruments for hedging rather than for speculative purposes.

The cross-sectional results support models of optimal hedging. Consistent with Froot, Scharfstein and Stein (1993), we provide evidence that interest-rate risk hedging within an institution is positively associated with ex ante growth opportunities. In our sample, those institutions which attained higher growth capacity at the time of conversion hedged interest-rate risk more than a control group of existing stock institutions during the three years following conversion. We also provide evidence consistent with Smith and Stulz (1985) that managerial security holdings are a significant determinant of hedging activity. We observe that managers which purchase greater than the median number of shares at conversion manage interest-rate risk significantly better than managers with relatively low share holdings beginning as early as seven quarters prior to conversion. This interest-rate risk reduction continues throughout the three-year period examined following conversion. In addition, for these thrifts with relatively high share ownership, the post-conversion interest-rate risk management is coordinated with an increase in credit risk. Finally, we report a negative association between managerial option holdings and interest-rate risk hedging. Managers holding relatively high numbers of options maintain a risky position on-balance sheet with respect to unexpected changes in interest rates. 
Appendix I

Sample of Converting Institutions

\begin{tabular}{|c|c|c|c|c|}
\hline & Docket $^{\mathrm{a}}$ & Cusip ${ }^{\mathrm{a}}$ & $\begin{array}{c}\text { Conversion } \\
\text { Date }\end{array}$ & $\begin{array}{c}\text { Institution } \\
\text { Name }^{\mathrm{b}} \\
\end{array}$ \\
\hline 1 & 0035 & 75108210 & $06 / 26 / 87$ & Raleigh Federal Savings Bank, NC \\
\hline 2 & 0070 & 79284810 & 05/15/87 & St. Paul Bancorp, Inc. \\
\hline 3 & 0092 & 93883210 & $05 / 14 / 87$ & Washington Federal Savings Bank (Washington D.C.) \\
\hline 4 & 0161 & 85338910 & $01 / 21 / 87$ & Standard Federal Bank \\
\hline 5 & 0200 & 23062610 & $05 / 14 / 87$ & Cumberland Federal Bancorp, Inc. \\
\hline 6 & 0347 & 31992810 & $02 / 27 / 85$ & First Federal Savings \& Loan Assoc. of Michigan \\
\hline 7 & 0360 & 16122310 & $03 / 20 / 84$ & Charter Federal Savings Bank \\
\hline & 0548 & 36760110 & $06 / 03 / 87$ & Gateway Federal Corp. \\
\hline 9 & 0647 & 43709010 & $10 / 10 / 86$ & Home Financial Corp. \\
\hline 10 & 0787 & 23286410 & $02 / 13 / 85$ & D\&N Financial Corp. \\
\hline 11 & 0796 & 35637310 & $12 / 11 / 84$ & Freedom Federal Savings Bank Oak Brook \\
\hline 12 & 0883 & 19764010 & $02 / 02 / 84$ & Columbia Federal Savings Bank, WA \\
\hline 13 & 0889 & 19790110 & $11 / 20 / 85$ & Columbia First Bank, A Federal Savings Bank \\
\hline 14 & 1042 & 31859810 & $05 / 14 / 86$ & First American Savings, F.A., PAc \\
\hline 15 & 1077 & 14011610 & $11 / 14 / 85$ & Capital Federal Savings \& Loan Association, CA \\
\hline 16 & 1165 & 08207210 & $12 / 16 / 86$ & Benjamin Franklin Federal Savings \& Loan Assoc. \\
\hline 17 & 1179 & 04878410 & $07 / 12 / 84$ & Atlantic Permanent Savings Bank, FSB \\
\hline 18 & 1213 & 37318610 & $01 / 25 / 84$ & Georgia Federal Bank, FSB, Atlanta \\
\hline 19 & 1223 & 87482910 & $12 / 16 / 86$ & Talman Home Federal Savings \& Loan Association \\
\hline 20 & 1266 & 36191710 & $12 / 02 / 88$ & GNW Financial Corp. \\
\hline 21 & 1270 & 57406110 & $06 / 02 / 87$ & Maryland Federal Bancorp, Inc. \\
\hline 22 & 1384 & 87227510 & $06 / 17 / 86$ & TCF Financial Corp. \\
\hline 23 & 1432 & 22621710 & $01 / 09 / 87$ & Crestmont Financial Corp. \\
\hline 24 & 1477 & 02941210 & $11 / 12 / 85$ & American Savings Bank, FSB (Tacoma, WA) \\
\hline 25 & 1484 & 77649310 & $01 / 23 / 87$ & Roosevelt Financial Group, Inc. \\
\hline 26 & 1573 & 19390110 & $02 / 07 / 84$ & Collective Federal Savings Bank \\
\hline 27 & 1777 & 31941810 & $05 / 09 / 84$ & First Capitol Financial Corp. \\
\hline 28 & 2051 & 62910410 & $08 / 15 / 86$ & NFS Financial Corp. \\
\hline 29 & 2143 & 03070010 & $10 / 30 / 86$ & Amerifirst Federal Savings \& Loan Assoc. (Miami, FL) \\
\hline 30 & 2167 & 54908910 & $12 / 15 / 86$ & Loyola Capital Corp. \\
\hline 31 & 2207 & 17667210 & $12 / 17 / 86$ & Citizens Security Group, Inc. \\
\hline 32 & 2254 & 95787810 & $01 / 23 / 85$ & Westerm Capital Investment Corp. \\
\hline 33 & 2322 & 36026610 & $01 / 14 / 87$ & Fulton Federal Savings Bank, GA \\
\hline 34 & 2354 & 32019B10 & $04 / 01 / 86$ & First Federal Savings Arkansas, FA \\
\hline 35 & 2371 & 07790010 & $02 / 11 / 87$ & Bell Savings Holdings, Inc. \\
\hline 36 & 2446 & 45470810 & $02 / 04 / 87$ & Indiana Federal Corp. \\
\hline 37 & 2521 & 43737710 & $10 / 30 / 86$ & Home Unity Savings \& Loan Association \\
\hline 38 & 2628 & $59160 \mathrm{C} 10$ & $11 / 04 / 88$ & Metro Bancshares \\
\hline 39 & 2641 & 16090310 & $01 / 22 / 88$ & Charter One Financial, Inc. \\
\hline 40 & 2708 & 06615710 & $04 / 24 / 84$ & Bankers First Corp. \\
\hline 41 & 2742 & 72014210 & $12 / 20 / 85$ & Piedmont Federal Corp. \\
\hline 42 & 2768 & 72390410 & $07 / 19 / 84$ & Pioneer Financial Corp. \\
\hline 43 & 2835 & 31993810 & $12 / 19 / 86$ & First Federal Savings \& Loan Assoc. of Chattanooga \\
\hline 44 & 2976 & 35352910 & $08 / 23 / 88$ & Franklin First Financial Corp. \\
\hline 45 & 3146 & 90659410 & $02 / 14 / 85$ & Union Federal Savings \& Loan Assoc. (Los Angeles) \\
\hline 46 & 3172 & 95737810 & $03 / 13 / 84$ & Westchester Financial Services, Corp. \\
\hline 47 & 3535 & 31859610 & 07/14/87 & First American Bancorp \\
\hline
\end{tabular}

See notes at end of appendix. 
Appendix I, continued

Sample of Converting Institutions

\begin{tabular}{|c|c|c|c|c|}
\hline & Docket $^{\mathrm{a}}$ & Cusip $^{\mathrm{a}}$ & $\begin{array}{l}\text { Conversion } \\
\text { Date }\end{array}$ & $\begin{array}{l}\text { Institution } \\
\text { Name }\end{array}$ \\
\hline 48 & 3572 & 39121110 & $03 / 02 / 84$ & Great Southern Federal Savings Bank, GA \\
\hline 49 & 3590 & 78413210 & $09 / 23 / 86$ & S.F. Federal Corp. \\
\hline 50 & 3658 & 12490310 & $05 / 15 / 85$ & CFS Financial Corp. \\
\hline 51 & 3687 & 94789010 & $12 / 12 / 86$ & Webster Financial Corp. \\
\hline 52 & 3696 & 43728510 & $05 / 24 / 84$ & Home Owners Federal S\&L Association, Boston \\
\hline 53 & 3778 & 64938910 & $01 / 22 / 88$ & New York Bancorp, Inc. \\
\hline 54 & 3865 & 95817010 & $01 / 24 / 84$ & Western Federal S\&L Assoc. (Marina Del Ray, CA) \\
\hline 55 & 3880 & 23291510 & $09 / 23 / 88$ & DF Southeastern, Inc. \\
\hline 56 & 4188 & 74352410 & $04 / 24 / 87$ & Prospect Park Financial Corp. \\
\hline 57 & 4410 & 70758310 & $08 / 12 / 86$ & $\begin{array}{l}\text { Sovereign Bancorp, Inc. (Holding Company for Penn } \\
\text { Savings Bank, (Wyomissing, PA) }\end{array}$ \\
\hline 58 & 4906 & 67458610 & $05 / 30 / 85$ & Occidental Nebraska Federal Savings Bank \\
\hline 59 & 4980 & 81434110 & 06/05/87 & Security Savings \& Loan Assoc. (Vineland, NJ) \\
\hline 60 & 5022 & 70149210 & $07 / 16 / 87$ & Parkvale Financial Corp. \\
\hline 61 & 5036 & 51490010 & $01 / 20 / 84$ & Landmark Savings Association (Pittsburgh) \\
\hline 62 & 5160 & 29200410 & $11 / 26 / 86$ & Empire of America Federal Savings Bank \\
\hline 63 & 5198 & 20164710 & $12 / 21 / 84$ & Commercial Federal Corporation \\
\hline 64 & 5266 & 31993610 & $01 / 13 / 87$ & First Federal Savings Bank of Puerto Rico (San Juan) \\
\hline 65 & 5271 & 59191110 & $11 / 15 / 85$ & Metropolitan Federal Bank FSB \\
\hline 66 & 5495 & 69637010 & $12 / 10 / 85$ & Calfed, Inc. \\
\hline 67 & 5794 & 43690310 & $05 / 18 / 84$ & Home Federal Bank FLA FSB (St. Petersburg) \\
\hline 68 & 5942 & 72387610 & 02/04/85 & Pioneer Savings Bank FSB \\
\hline 69 & 5970 & 98663010 & $02 / 28 / 84$ & York Financial Corp. \\
\hline 70 & 6275 & 95817110 & $02 / 14 / 85$ & Western Federal Savings Bank (Puerto Rico) \\
\hline 71 & 6316 & 73234110 & $02 / 15 / 84$ & Ponce Federal Bank FSB \\
\hline 72 & 6579 & 71427510 & $08 / 17 / 84$ & Perpetual Financial Corporation \\
\hline 73 & 7046 & 19039M10 & $12 / 17 / 85$ & Coast Savings Financial, Inc. \\
\hline 74 & 7354 & 07262L10 & $05 / 09 / 86$ & Bay View Capital Corp. \\
\hline 75 & 7424 & 17665610 & $01 / 14 / 87$ & Citizens Savings Bank NY \\
\hline 76 & 7708 & 73865910 & $11 / 19 / 85$ & Poughkeepsie Savings Bank FSB NY \\
\hline 77 & 7776 & 02940410 & $11 / 20 / 85$ & American Savings Bank FSB NY \\
\hline 78 & 7812 & 22790110 & $10 / 23 / 85$ & Crossland Savings FSB Brooklyn \\
\hline 79 & 7814 & 03311910 & 04/07/87 & Anchor Savings Bank FSB NY \\
\hline 80 & 7837 & 25432R10 & 08/19/86 & Dime Savings Bank FSB NY \\
\hline 81 & & 97179510 & $11 / 26 / 86$ & Wilmington Savings Fund Society FSB \\
\hline
\end{tabular}

See notes at end of appendix. 
Appendix I, continued

Control Sample of Stock-Charted Institutions

\begin{tabular}{|c|c|c|c|}
\hline & Docket $^{\mathrm{a}}$ & Cusip $^{a}$ & Institution Name ${ }^{b}$ \\
\hline 1 & 1914 & 00867710 & H.F. Ahmanson \& Co. \\
\hline 2 & 6368 & 33753110 & First Western Financial Corp. \\
\hline 3 & 3742 & 39144210 & Great Western Financial Corp. \\
\hline 4 & 4271 & 68029310 & Old Stone Corporation \\
\hline 5 & 3805 & 02524220 & $\begin{array}{l}\text { American Continental Corp. (Holding Company for } \\
\text { Lincoln Savings and Loan Assoc., Irvine, CA) }\end{array}$ \\
\hline 6 & 6298 & 02507820 & American Century Corporation \\
\hline 7 & 6189 & 26103910 & Downey Savings \& Loan Association \\
\hline 8 & 1314 & 30735110 & Farwest Financial Corporation \\
\hline 9 & 2079 & 31744110 & Financial Corporation of Santa Barbara \\
\hline 10 & 7796 & 02889610 & American Pioneer Savings Bank \\
\hline 11 & 1703 & 11138810 & Broadview Savings Bank \\
\hline 12 & 2745 & 15640LA0 & Centrust Savings Bank (Miami, FL) \\
\hline 13 & 6474 & 31381510 & $\begin{array}{l}\text { Bayamon Federal Savings \& Loan Assoc., FSB } \\
\text { (Puerto Rico) }\end{array}$ \\
\hline 14 & 6717 & 38131710 & Golden West Financial Corporation \\
\hline 15 & 5442 & 42054210 & Hawthorne Financial Corporation \\
\hline 16 & 1761 & 45272210 & Imperial Corporation of America \\
\hline 17 & 6649 & 58940810 & Mercury Savings and Loan Association \\
\hline 18 & 1920 & 95943210 & Western Savings and Loan Assoc. (Phoenix, AZ) \\
\hline 19 & 7277 & 37465810 & Gibraltar Financial Corporation \\
\hline 20 & 6120 & 01140210 & Alamo Savings Association (Texas) \\
\hline 21 & 0115 & 11816610 & Buckeye Financial Corporation \\
\hline 22 & 5579 & 12633510 & CSF Holdings, Inc. \\
\hline 23 & 1531 & 17876210 & Cityfed Financial Corporation \\
\hline 24 & 2650 & 32022710 & First Financial Corp., WI \\
\hline 25 & 1677 & 40073910 & Guarantee Financial Corporation (California) \\
\hline 26 & 7103 & 42722910 & Heritage Financial Corporation \\
\hline 27 & 4549 & 51466710 & Land of Lincoln Savings and Loan Association \\
\hline 28 & 6762 & 02362210 & Ameribanc Investors Group, Inc. \\
\hline 29 & 1482 & 89352810 & Transcapital Financial Corporation \\
\hline 30 & 7414 & 62884710 & NCF Financial Corporation \\
\hline 31 & 5405 & $02941 \mathrm{H} 30$ & American Savings of Florida, FSB \\
\hline 32 & 5692 & 05945110 & Bancflorida Financial Corporation \\
\hline 33 & 1161 & 43771410 & Homestead Financial Corporation \\
\hline 34 & 4426 & $33761 \mathrm{P} 10$ & Firstcorp, Inc. \\
\hline 35 & 5551 & 06605610 & Bankatlantic Financial Corporation \\
\hline 36 & 2036 & 83576310 & Sooner Federal Savings and Loan Association (OK) \\
\hline
\end{tabular}

${ }^{a}$ The docket number represents a thrift-specific identification number assigned by the Office of Thrift Supervi (formerly the FHLBB). The Cusip number is from CRSP.

${ }^{\mathrm{b}}$ The institution name is as of the time of conversion. In cases where matching the institution to the hole company is confusing, we provide the holding company name or geographic location of the institution.

${ }^{c}$ On Junc 15, 1989, First American Savings, F.A. completed its reorganization as a holding company by exchan: its shares of common stock for those issued by Flagship Financial Corporation (Cusip \#33841310). transaction occurred after the sample period. 


\section{Appendix II}

Excerpts from "Section H, Maturity and Yield/Cost Information" Instructions (January 1989)

\section{IMPACT OF HEDGING ACTIVITIES ON ASSETS}

Certain hedging activities and other transactions synthetically change the effective maturity/repricing structure of the institution's financial assets. Report the total effect of these hedging and related activities on the maturity/repricing structure of financial assets on these lines.

Include the effects of the following activities and transactions, provided they were entered into for the purpose of hedging:

1. Open interest-rate futures contracts;

2. Open long-put options contracts having a strike price at or in-the-money when the option was acquired;

3. Firm commitments to sell assets; and

4. Other similar off-balance-sheet activities.

Each hedging activity/transaction should be accounted for as follows:

1. Record the amount of the hedged asset in the original "maturity/repricing" column of the hedged asset as a negative number; and

2. Record the amount of the hedged asset in the "maturity/repricing" column achieved by the hedge as a positive number.

\section{IMPACT OF HEDGING ACTIVITIES ON LIABILITIES}

Certain hedging activities and other transactions synthetically change the effective maturity/repricing structure of the institution's financial liabilities. Report the total effect of these hedging and related activities on the maturity/repricing structure of financial liabilities on these lines.

Include the effects of the following activities and transactions, provided they were entered into for the purpose of hedging:

1. Open interest-rate futures contracts;

2. Open long-put options contracts having a strike price at or in-the-money when the option was acquired;

3. Interest-rate swaps; 


\section{Appendix II, continued}

4. Interest-rate caps: Determine the amount to be reported as hedging activity as follows:

a. If, at the end of the quarter, the CAP index rate for any maturity is within 50 basis points of the prespecified contractual CAP rate, include 100 percent of the notional principal of the CAP for the hedge; or

b. If, at the end of the quarter, the current market index rate was more than 50 basis points lower than the prespecified contractual CAP rate, contract the ICR Coordinator or the FHL Bank to which the reporting institution submits its reports to obtain a table which should be used to find the percentage of the CAP's notional value to be considered as a hedge.

\section{SAMPLE TABLE}

\section{Percentage of Notional Value Allowed for Impact of Hedging for "Out-of-the-Money" CAPS}

Number of Basis Points "Out-of-the-Money" at the End of Quarter

\begin{tabular}{|c|c|c|c|c|c|c|c|}
\hline $\begin{array}{c}\text { Remaining } \\
\text { Maturity } \\
\text { (Years) }\end{array}$ & $\begin{array}{c}50 \\
\text { or } \\
\text { Less }\end{array}$ & $\begin{array}{c}51- \\
100\end{array}$ & $\begin{array}{c}101- \\
200\end{array}$ & $\begin{array}{c}201- \\
300\end{array}$ & $\begin{array}{c}301- \\
400\end{array}$ & $\begin{array}{c}401- \\
500\end{array}$ & $\begin{array}{c}501 \\
\text { or } \\
\text { More }\end{array}$ \\
\hline$<2$ & $100 \%$ & $69 \%$ & $47 \%$ & $29 \%$ & $17 \%$ & $11 \%$ & $3 \%$ \\
\hline $2-4$ & $100 \%$ & $74 \%$ & $55 \%$ & $37 \%$ & $25 \%$ & $17 \%$ & $6 \%$ \\
\hline $4-6$ & $100 \%$ & $80 \%$ & $64 \%$ & $47 \%$ & $35 \%$ & $26 \%$ & $12 \%$ \\
\hline$>6$ & $100 \%$ & $86 \%$ & $74 \%$ & $61 \%$ & $50 \%$ & $41 \%$ & $25 \%$ \\
\hline
\end{tabular}

Using the example table provided above, assume that the market index rate at the end of the quarter was $71 / 2$ percent and the reporting institution held a CAP with 3 years remaining to maturity, a $\$ 10$ million notional value, and an 8 1/4 percent prespecified contractual CAP rate. The CAP was 75 basis points "out-of-the-money" at the end of the quarter and the appropriate table percentage to apply to the notional principal is 74 percent. Thus, $\$ 7.4$ million (74 percent of the $\$ 10$ million notional principal) is considered as a hedge.

5. Other similar off-balance-sheet activities.

Each hedging activity/transaction should be reported as follows:

1. Record the amount of the hedged liability in the original "maturity/repricing" column of the hedged liability as a negative number.

2. Record the amount of the hedged liability in the "maturity/repricing" column achieved by the hedge as a positive number. 


\section{Appendix III}

As a test of the robustness of our measure of interest-rate risk, we provide evidence from stock-market returns about the market's perception of interest-rate sensitivity for the sample of converting institutions. We hypothesize that, as interest-rate sensitivity measured by NET/TA increases (becomes more negative), interest-rate sensitivity measured by $\lambda_{b}$ in equation (5) will likewise be increasing,

$$
\mathrm{R}_{\mathrm{pw}}=\alpha_{\mathrm{p}}+\beta_{\mathrm{p}} \mathrm{R}_{\mathrm{mw}}+\lambda_{\mathrm{p}} \mathrm{R}_{\mathrm{iw}}+\mathrm{e}_{\mathrm{pw}} .
$$

In equation (5), $\mathrm{R}_{\mathrm{pw}}$ is the weekly holding-period return for a portfolio of converting institutions, $\mathrm{R}_{\mathrm{mw}}$ is the weekly holding-period return for the NASDAQ market, and $\mathrm{R}_{\mathrm{iw}}$ is the weekly holdingperiod return for a portfolio of either 90-day Treasury bills or 20-year non-callable Treasury bonds. (All returns are obtained from CRSP.) Equation (5) is estimated for portfolios (p) of converting institutions which are formed by ranking institutions based on their net gap positions (NET/TA). In theory, a financial institution's expected value depends on unexpected changes in interest rates (which proxy for unexpected inflation) as described by the nominal contracting hypothesis (French, Ruback, and Schwert, 1983). Accordingly, cross-sectional differences in interest-rate sensitivity as measured by $\lambda_{\mathrm{D}}$ should be related to differences in the maturity mismatch of the net assets of the firms in the portfolio. In support of this hypothesis, prior literature documents the interest-rate sensitivity of the market value of financial institutions. (See, for example, Flannery and James, 1984; Kane and Unal, 1990.)

We estimate equation (5) over the six-year period 1984 through 1989. Although preliminary results indicated a significant association between NET/TA and market interest-rate sensitivity, the results also suggested a potential lack of structural stability of the model parameters across the entire sample period. Therefore, we separately analyze three sub-periods: 1984 to 1985 , 1986 to 1987, and 1988 to 1989. Panel A of Table A shows the differences among descriptive statistics for the holding period returns on the market portfolio $\left(\mathrm{R}_{\mathrm{mw}}\right)$ and the interest-rate 
portfolios $\left(R_{i v}\right)$ over the entire six-year period. The standard deviations of $R_{m w}$ and $R_{i v}$, measured using portfolios of either T-bills and T-bonds, are approximately two times greater during the period 1986 to 1987 (which includes the 1987 stock market crash) than those in either the earlier or latter period. Consequently, in addition to estimating equation (5) over the entire sixyear period, we also estimate equation (5) separately over each of the two-year periods.

\section{[INSERT TABLE A HERE]}

The results of estimation of equation (5) are presented in Table B. We form portfolios by dividing the sample of converting institutions into five portfolios of equal size based on their interest-rate risk measured by NET/TA. Institutions with net gap positions closest to zero are assigned to the lowest interest-rate risk portfolio $(1=\mathrm{LOW})$; institutions with the most negative net gap positions are assigned to the highest interest-rate risk portfolio $(5=\mathrm{HIGH})$. The risk portfolios are redefined annually based on each institution's net gap position at the beginning of the year over which equation (5) is estimated. ${ }^{36}$ On average, institutions in the LOW portfolio have a net one-year gap ratio to total assets of -0.15 compared to -0.52 for institutions in the HIGH portfolio. This ratio declines approximately 0.1 across each of the five portfolios.

\section{[INSERT TABLE B HERE]}

The results suggest that our proxy for interest-rate sensitivity (NET/TA) is consistent with the interest-rate sensitivity measured by the estimated coefficients on $\mathrm{R}_{\mathrm{iw}}$. Specifically, the estimated coefficients on a portfolio of T-bills $\left(\lambda_{\text {BILL }}\right)$ increase as interest-rate risk increases from LOW to HIGH over the entire six-year period. In addition, interest-rate sensitivity to holdingperiod returns on a portfolio of 20 -year non-callable bonds $\left(\lambda_{\mathrm{BOND}}\right)$ increases across the five portfolios as risk measured by XSNET increases. The interest-rate sensitivities of the LOW and HIGH-risk portfolios are significantly different during the full sample period as well as in the subperiods 1984 to 1985 and 1986 to 1987. In fact, for 1984 to 1985 and 1986 to 1987, market interest-rate sensitivity measured by T-bonds is not significantly different from zero for the LOW risk portfolios while the estimated coefficients are significant and increasing across portfolios four

\footnotetext{
${ }^{36}$ Redefining the portfolios quarterly does not change the results.
} 
and five. Likewise, short-term interest-rate sensitivity for the low interest-rate risk institutions (portfolios 1-3) is not significantly different from zero for the period 1986 to 1987.

These results indicate that one-year net gap is a good measure of exposure, especially to changes in long-term interest rates. These findings of an association between net interest-rate sensitivity measured by NET/TA and market interest-rate sensitivity for both T-bills and T-bonds, during the entire six-year period result mainly from activity in the 1986 to 1987 period of high interest-rate volatility. 


\section{Appendix III: Table A}

Descriptive Statistics of Proxies for Holding-Period Returns on the Thrift, Market, and Interest-Rate Portfolios, 1984 - 1989

Panel A: Descriptive Statistics of $R_{p}, R_{m} w$ and $R_{i w} a$

\begin{tabular}{|c|c|c|c|c|c|c|c|c|c|c|c|c|}
\hline & \multicolumn{4}{|c|}{$1984-1985$} & \multicolumn{4}{|c|}{$1986-1987$} & \multicolumn{4}{|c|}{$1988-1989$} \\
\hline & $\mathrm{R}_{\mathrm{pw}}$ & $\mathrm{R}_{\mathrm{mw}}$ & $i=T$-bill & $i=T$-bond & $\mathrm{R}_{\mathrm{pw}}$ & $\mathbf{R}_{\mathrm{mw}}$ & $i=T$-bill & $\begin{array}{l}\mathrm{iww} \\
i=T \text {-bond }\end{array}$ & $\mathbf{R}_{\mathrm{pw}}$ & $\mathrm{R}_{\mathrm{mw}}$ & $i=T$-bill & $i=T$-bond \\
\hline Mean & 0.00736 & 0.00097 & 0.00172 & 0.00410 & -0.00023 & 0.00112 & 0.00117 & 0.00226 & 0.00052 & 0.00440 & 0.00143 & 0.00248 \\
\hline Std. Dev. & 0.05191 & 0.01364 & 0.00052 & 0.01379 & 0.06438 & 0.02360 & 0.00068 & 0.02037 & 0.06699 & 0.01089 & 0.00039 & 0.01098 \\
\hline Minimum & -0.57692 & -0.03721 & 0.00021 & -0.02731 & -0.77778 & -0.16368 & -0.00011 & -0.04699 & -0.84615 & -0.02424 & 0.00049 & -0.02106 \\
\hline Maximum & 0.44444 & 0.04171 & 0.00299 & 0.03481 & 1.09869 & 0.06174 & 0.00626 & 0.09892 & 2.50000 & 0.06020 & 0.00240 & 0.03556 \\
\hline
\end{tabular}

Panel B: Correlation Tables ${ }^{a}$

\begin{tabular}{|c|c|c|c|c|c|c|c|c|c|}
\hline & \multicolumn{3}{|c|}{$1984-1985$} & \multicolumn{3}{|c|}{$1986-1987$} & \multicolumn{3}{|c|}{$1988-1989$} \\
\hline & $\mathrm{R}_{\mathrm{pw}}$ & $\mathrm{R}_{\mathrm{mw}}$ & $\mathrm{R}_{\mathrm{iw}}$ & $\mathrm{R}_{\mathrm{pw}}$ & $\mathrm{R}_{\mathrm{mw}}$ & $\mathrm{R}_{\mathrm{iw}}$ & $\mathrm{R}_{\mathrm{pw}}$ & $\mathrm{R}_{\mathrm{mw}}$ & $\mathrm{R}_{\mathrm{iw}}$ \\
\hline & & & $i=T$-bill $\quad i=T$-bond & & & $i=T$-bill $\quad i=T$-bond & & & $i=T$-bill $\quad i=T$-bond \\
\hline $\mathrm{R}_{\mathrm{mw}}$ & $0.2341 * *$ & & & $0.3871 * *$ & & & $0.2006 * *$ & & \\
\hline $\mathrm{R}_{\mathrm{T}-\mathrm{BILL}, \mathrm{w}}$ & -0.0099 & -0.1555 & & $-0.1843 * *$ & $-0.5231 * *$ & & $-0.0025 * *$ & -0.0389 & \\
\hline $\mathrm{R}_{\mathrm{T}-\mathrm{BOND}, \mathrm{w}}$ & $0.0934 * *$ & 0.1603 & $0.4044 * *$ & $0.0316 * *$ & -0.1064 & $0.5981 * *$ & $0.0199 * *$ & 0.0511 & $0.4051 * *$ \\
\hline
\end{tabular}

**Significantly different from zero at the $1 \%$ level.

$\mathrm{R}_{\mathrm{pw}}=$ weekly holding-period return for a portfolio of converting institutions.

$\mathrm{R}_{\mathrm{mw}}=$ weekly holding-period return on the NASDAQ market portfolio.

$\mathrm{R}_{\mathrm{iw}}=$ weekly holding-period retum on a portfolio of 90-day Treasury bills or 20-year non-callable Treasury bonds.

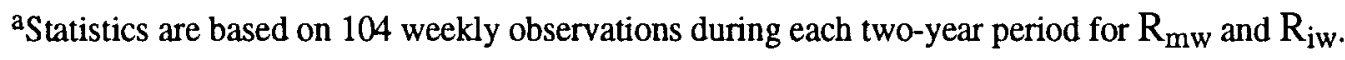




\section{Appendix III: Table B}

Results of Weekly Estimation of a Two-Factor Market Model for the Sample of Converting Institutions from 1984 to 1989 and Three Sub-Periods: 1984 - 1985, 1986 - 1987, and 1988 - 1989

Equation (5): $R_{\mathrm{pw}}=\alpha_{\mathrm{p}}+\beta_{\mathrm{p}} \mathrm{R}_{\mathrm{mw}}+\lambda_{\mathrm{p}} \mathrm{R}_{\mathrm{iw}}+\mathrm{e}_{\mathrm{pw}}$

\begin{tabular}{|c|c|c|c|c|c|c|c|c|c|c|c|c|}
\hline \multirow[t]{3}{*}{ Five $p$} & \multicolumn{3}{|c|}{ s: LOW (1) to HIGH (5) I } & \multicolumn{3}{|c|}{ rest-rate risk ${ }^{\mathrm{a}}$} & \multirow{2}{*}{\multicolumn{3}{|c|}{$1986-1987$}} & \multirow{2}{*}{\multicolumn{3}{|c|}{$1988-1989$}} \\
\hline & & $1984-1989$ & & & $1984-198$ & & & & & & & \\
\hline & $\beta_{\mathrm{p}}$ & $\lambda_{\mathrm{BILL}}$ & $\lambda_{\mathrm{BOND}}$ & $\beta_{\mathrm{p}}$ & $\lambda_{\mathrm{BILL}}$ & $\lambda_{\mathrm{BOND}}$ & $\beta_{\mathrm{p}}$ & $\lambda_{\mathrm{BILL}}$ & $\lambda_{\mathrm{BOND}}$ & $\beta_{\mathfrak{p}}$ & $\lambda_{\mathrm{BILL}}$ & $\lambda_{\mathrm{BOND}}$ \\
\hline \multicolumn{13}{|l|}{ Portfolio p: } \\
\hline 1 - LOW & $1.163 * *$ & $6.771^{*}$ & $0.240^{* *}$ & $1.505 * *$ & 5.661 & -0.026 & $0.982 * *$ & 5.143 & $0.311 *$ & $1.598 * *$ & 2.513 & 0.173 \\
\hline 2 & $1.194^{* *}$ & $7.090^{*}$ & $0.240 * *$ & $1.306 * *$ & 5.787 & -0.101 & $1.168 * *$ & 7.941 & $0.371 * *$ & $1.324 * *$ & -0.036 & 0.179 \\
\hline 3 & $1.328 * *$ & $7.680 * *$ & $0.432 * *$ & $1.339 * *$ & 5.678 & $0.495^{*}$ & $1.323^{* *}$ & 7.990 & $0.496 * *$ & $1.442 * *$ & 3.362 & 0.016 \\
\hline 4 & $1.389 * *$ & $7.584 * *$ & $0.479 * *$ & $1.009 * *$ & 2.783 & $0.531 * *$ & $1.527 * *$ & $9.808 *$ & $0.496 * *$ & $1.518 * *$ & 11.153 & 0.370 \\
\hline 5 - HIGH & $1.286 * *$ & $9.736 * *$ & $0.593 * *$ & $1.045 * *$ & 2.627 & $0.636^{*}$ & $1.381 * *$ & $15.674 * *$ & $0.632 * *$ & $1.556^{* *}$ & 5.387 & $0.327^{*}$ \\
\hline \multicolumn{13}{|l|}{ F-Test of } \\
\hline $\mathrm{LOW}=\mathrm{HIGH}^{\mathrm{c}}$ & & 0.46 & $5.41 *$ & & 0.08 & $2.80^{*}$ & & $2.88 *$ & $3.65^{*}$ & & 0.11 & 0.25 \\
\hline Adjusted $\mathrm{R}^{2}$ & & $23 \%-44 \% b$ & $23 \%-47 \%$ & & $6 \%-32 \%$ & $9 \%-31 \%$ & & $37 \%-64 \%$ & $39 \%-68 \%$ & & $18 \%-44 \%$ & $18 \%-46 \%$ \\
\hline
\end{tabular}

$* *(*)$ Significant at the $1 \%(10 \%)$ level, respectively

anterest-rate-risk portfolios are defined based on NET/TA, the ratio of net one-year gap after impact of off-balance sheet activities/total assets.

${ }^{b}$ Range of Adjusted $\mathrm{R}^{2} \mathrm{~s}$ for all portfolios.

${ }^{c} F$ value of the test of the equality of $\lambda$ (BILL and BOND) across the LOW and HIGH interest-rate risk portfolios.

\section{Variable Definitions:}

$\mathrm{R}_{\mathrm{pw}}=$ weekly holding-period return for a portfolio of converting institutions.

$\mathrm{R}_{\mathrm{mw}}=$ weekly holding-period retum on the NASDAQ market index.

$\mathrm{R}_{\mathrm{iw}}=$ weekly holding-period return on a portfolio of 90 -day Treasury bills or 20 -year non-callable Treasury bonds. 


\section{References}

Asquith, Paul and David W. Mullins, Jr. 1986. "Equity Issues and Offering Dilution," Journal of Financial Economics 15, 61-89.

Barth, R. James, Philip F. Bartholomew and Michael G. Bradley. 1990. "Determinants of Thrift Institution Resolution Costs," Journal of Finance 45, 731-754.

Bennett, Dennis E., Roger D. Lundstrom, and Donald G. Simonson, 1986. "Estimating Portfolio Net Worth Values and Interest-Rate Risk in Savings Institutions," in Federal Reserve Bank of Chicago, ed.: Proceedings: A Conference on Bank Structure and Competition (Federal Reserve Bank of Chicago, Chicago, Ill.).

Bierwag, G. O. and George G. Kaufman. 1985. "Duration Gap for Financial Institutions," Financial Analysts Journal, 68-71.

Campbell, Tim S. and William A. Kracaw. 1990. "Corporate Risk Management and the Incentive Effects of Debt," Journal of Finance 45, 1673-1686.

Carter, Richard B. and Roger D. Stover. 1991. "Management Ownership and Firm Compensation Policy: Evidence from Converting Savings and Loan Associations," Financial Management, 80-90.

Chicago Mercantile Exchange. 1987. Futures and Options Trading for Savings and Loan Associations: The Regulatory Environment, CME White Paper Series, no. 3. (Chicago Mercantile Exchange, Chicago, Ill.).

Cordell, Lawrence R., Gregor D. MacDonald and Mark E. Wohar. 1993. "Corporate Ownership and the Thrift Crisis," Journal of Law and Economics, 719-756.

Diamond, Douglas W. 1984. "Financial Intermediation and Delegated Monitoring," Review of Economic Studies, 393-414.

Diamond, Douglas W. and Robert E. Verrecchia. 1982. "Optimal Managerial Contracts and Equilibrium Security Prices, The Journal of Finance 37, 275-287.

Ederington, Louis H. 1979. "The New Futures Market,” Journal of Finance, 157-170.

Edwards, Franklin R. 1981. "The Regulation of Futures and Forward Trading by Depository Institutions: A Legal and Economic Analysis,” Journal of Futures Markets, 201-218.

Flannery, Mark J. and Christopher M. James. 1984. "The Effect of Interest Rate Changes on the Common Stock Returns of Financial Institutions," Journal of Finance, 1141-1153.

Fleck, Larry. 1990. Status of Conversions, Office of Thrift Supervision, Unpublished Memorandum (January 11).

French, Kenneth R., Richard S. Ruback and G. William Schwert. 1983. "Effects of Nominal Contracting on Stock Returns," Journal of Political Economy, 70-96.

Froot, Kenneth, David Scharfstein and Jeremy Stein. 1993. "Risk management: Coordinating Investment and Financing Policies," The Journal of Finance 48, 1629-1658. 
Froot, Kenneth and Jeremy Stein. 1995. "Risk Management, Capital Budgeting and Capital Structure Policy for Financial Institutions: An Integrated Approach," Working Paper, Harvard Business School.

Got-ton, Gary and Richard Rosen. 1995. "Banks and Derivatives," Working Paper, University of Pennsylvania.

Hadaway, L. Beverly and Samuel C. Hadaway. 1981. "An Analysis of the Performance Characteristics of Converted Savings and Loan Associations." The Journal of Financial Research. Vol 4. No 3 (Fall).

Hansell, Saul and Kevin Muehring. 1992. "Why Derivatives Rattle the Regulators." Institutional Investor, (September), 49-62.

Kane, J. Edward. 1985. The Gathering Crisis in Federal Deposit Insurance. Cambridge, Mass: MIT Press.

Kane, J. Edward. 1989. The S\&L Insurance Mess: How did it Happen? Washington D.C., The Urban Institute Press.

Kane, J. Edward and Haluk Unal. 1990. "Modeling Structural and Temporal Variation in the Market's Valuation of Banking Firms," Journal of Finance 45, 113-136.

Lewent, Judy and A. John Kearney. 1990. "Identifying, Measuring and Hedging Currency Risk at Merck, Journal of Applied Corporate Finance, 19-28.

Maksimovic, Vojislav and Haluk Unal. 1993. "Issue Size Choice and "Underpricing" in Thrift Mutual-to-Stock Conversions," Journal of Finance 48, 1659-92.

Mason, Scott P. 1995. "The Allocation of Risk," Working Paper 95-060, Harvard Business School.

Masulis, W. Ronald. 1987. "Changes in Ownership Structure: Conversions of Mutual Savings and Loans to Stock Charter," Journal of Financial Economics 18, 29-59.

Masulis, W. Ronald and Ashok N. Korwar. 1986. "Seasoned Equity Offerings: An Empirical Investigation," Journal of Financial Economics 15, 91-118.

Myers, Stewart C. 1977. "Determinants of Corporate Borrowing," Journal of Financial Economics $5,147-175$.

Myers, Stewart C. and Nicholas S. Majluf. 1984. Corporate Financing and Investment Decisions When Firms Have Information That Investors Do Not Have," Journal of Financial Economics 13, 187-221.

Nance, Deana R., Clifford W. Smith, Jr., and Charles W. Smithson, 1993, "On the Determinants of Corporate Hedging," The Journal of Finance, 267-284.

O'Hara, Maureen and Wayne Shaw. 1990. "Deposit Insurance and Wealth Effects: The Value of Being Too Big to Fail," Journal of Finance 45, 1587-1600.

Petzel, Todd E. 1989. Financial Futures and Options: A Guide to Markets, Applications, and Strategies. Westport, Connecticut: Quorum Books.

Pilloff, Steven J. 1994. “The Impact of Derivatives on Bank Risk and Value," Working Paper, University of Pennsylvania. 
Rasmusen, Eric. 1988. "Mutual Banks and Stock Banks." Journal of Law and Economics 31. (October), 395-421.

Schrand, Catherine M. 1994. "An Evaluation of the Effects of Accounting Rules on Interest Rate Risk Management in the Savings and Loan Industry." In Proceedings: A Conference on Bank Structure and Competition, by the Federal Reserve Bank of Chicago. Chicago: Federal Reserve Bank of Chicago, 186-207.

Schrand, Catherine M. 1994. "The Information Content of Disclosures about Derivative Instruments," Working Paper, University of Pennsylvania.

Simons, Katerina. 1992. "Mutual-to-Stock Conversions by New England Savings Banks: Where Has All the Money Gone?" New England Economic Review. (March/April).

Sinkey, Joseph F. and David Carter. 1994. "On the Use and Determinants of Bank Derivatives," Working Paper, University of Georgia.

Smith, Clifford and Rene Stulz. 1985. "The Determinants of Firms' Hedging Policies," The Journal of Financial and Quantitative Analysis 28, 391-405.

Tufano, Peter. 1995. "Who Manages Risk? An Empirical Examination of Risk Management Practices in the Gold Mining Industry." Working Paper, Harvard Business School.

Unal, Haluk. 1995. "Regulatory Misconceptions in Pricing Thrift Conversions: A Closer Look at the Appraisal Process." Working Paper, University of Maryland.

United States League of Savings Institutions. Savings Institutions Sourcebook. Washington D.C.: United States League of Savings Institutions, 1988.

Verbrugge, A. James and Steven Goldstein. 1981. "Risk Return and Managerial Objectives: Some Evidence from the Savings and Loan Industry." The Journal of Financial Research. Vol 4. No. 1 (Spring).

White, Halbert. 1980. "A Heteroskedasticity-Consistent Covariance Matrix Estimator and a Direct Test for Heteroskedasticity." Econometrica 48, 817-838.

Williams, L. Julie, J. L. Fleck and V.G. Comizio. 1987. "Mutual-to-Stock Conversions: New Capitalization Opportunities and Post-Conversion Control Developments." Legal Bulletin of the U.S. League of Savings Institutions, 237-317. 
Figure 1

Time-Series Means and Confidence Bands for the Control Variables, Interest-Rate-Risk Variables and Credit-Risk Variables for the Sample of Converting Thrifts

TA (in thousands)

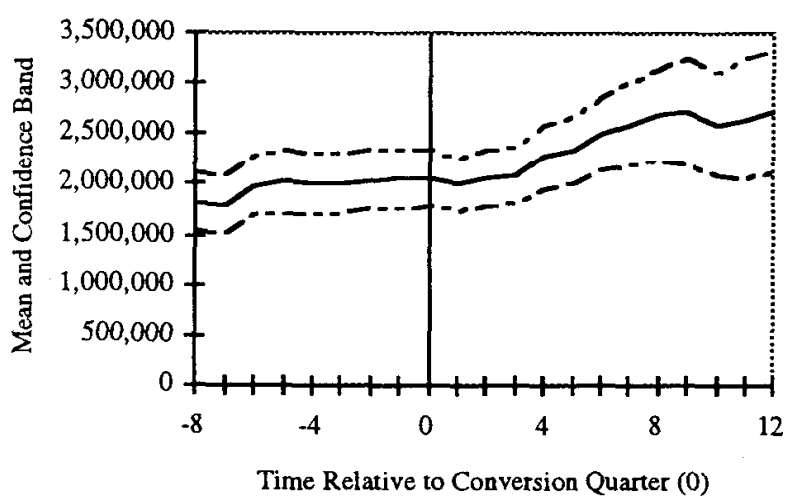

GAP/TA

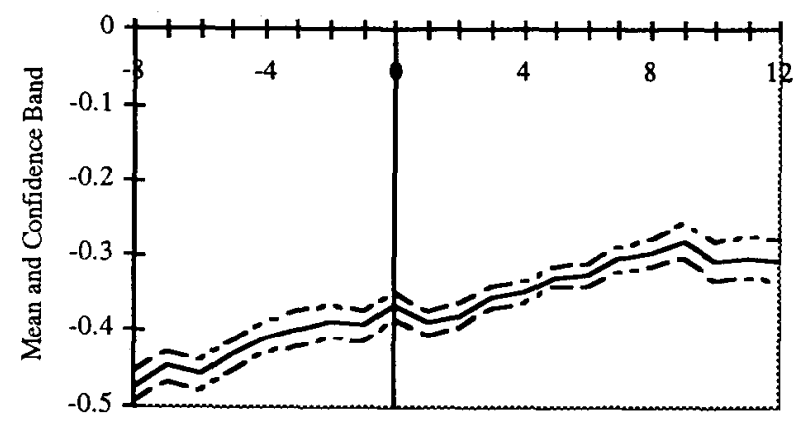

Time Relative to Conversion Quarter (0)
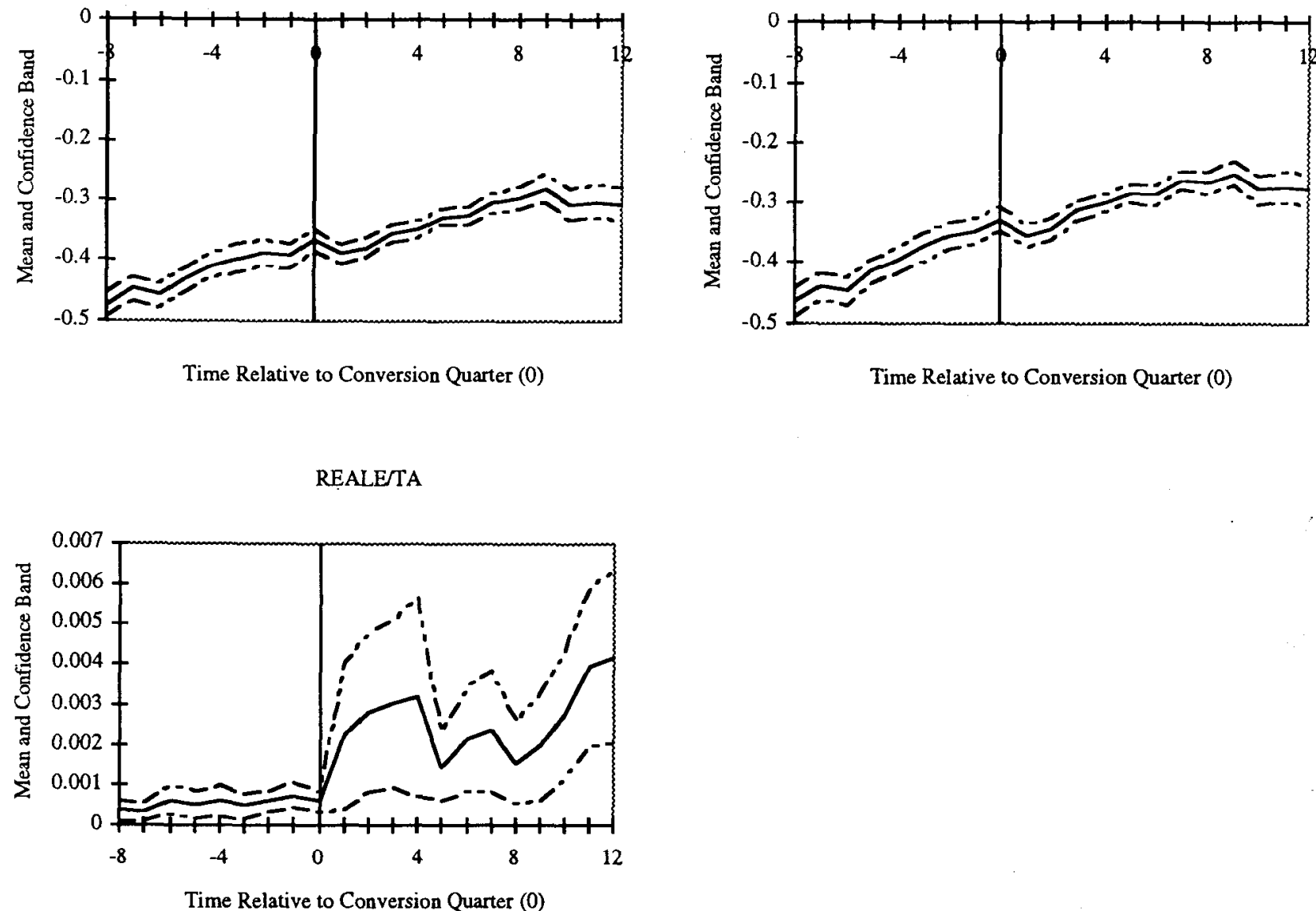

Time Relative to Conversion Quarter (0)

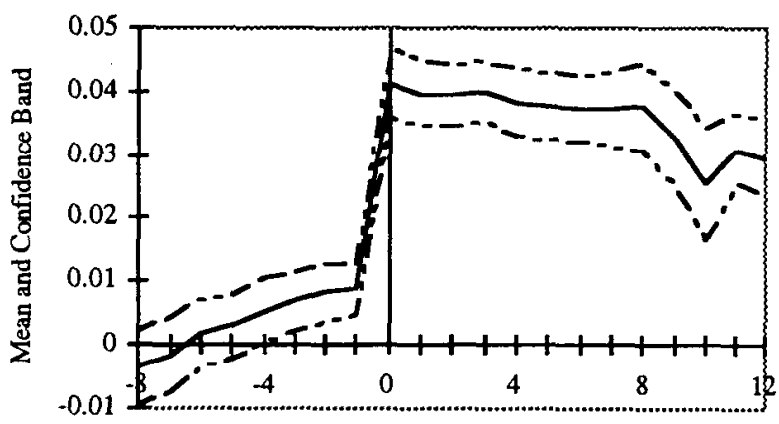

Time Relative to Conversion Quarter (0)

NET/TA 
Table I

Summary of Thrift Industry Conversions

\begin{tabular}{|c|c|c|c|c|c|c|c|c|c|}
\hline & 1980 & 1981 & 1982 & 1983 & 1984 & 1985 & 1986 & 1987 & 1988 \\
\hline \multicolumn{10}{|c|}{ Panel A: Savings-and-Loan Industry (FSLIC-insured) } \\
\hline $\begin{array}{l}\text { No. of Institutions } \\
\text { Total Assets (\$bil) } \\
\text { Net Worth (\$bil) } \\
\text { Net Income (\$mil) }\end{array}$ & $\begin{array}{r}3,993 \\
\$ 604 \\
\$ 32 \\
\$ 781\end{array}$ & $\begin{array}{r}3,751 \\
640 \\
27 \\
(4,631)\end{array}$ & $\begin{array}{r}3,287 \\
686 \\
20 \\
(4,142)\end{array}$ & $\begin{array}{r}3,146 \\
814 \\
25 \\
1,945\end{array}$ & $\begin{array}{r}3,136 \\
978 \\
27 \\
1,022\end{array}$ & $\begin{array}{r}3,246 \\
1,070 \\
34 \\
3,728\end{array}$ & $\begin{array}{r}3,220 \\
1,164 \\
39 \\
131\end{array}$ & $\begin{array}{r}3,147 \\
1,251 \\
34 \\
(7,779)\end{array}$ & $\begin{array}{c}2,949 \\
1,352 \\
46 \\
(12,057)\end{array}$ \\
\hline $\begin{array}{l}\text { Stock Institu } \\
\text { (\% of Institutions) } \\
\text { (\% of Total Assets) }\end{array}$ & $\begin{array}{l}\text { tions: } \\
20 \% \\
27 \%\end{array}$ & $\begin{array}{l}21 \\
29\end{array}$ & $\begin{array}{l}23 \\
30\end{array}$ & $\begin{array}{l}24 \\
40\end{array}$ & $\begin{array}{l}30 \\
52\end{array}$ & $\begin{array}{l}33 \\
56\end{array}$ & $\begin{array}{l}37 \\
62\end{array}$ & $\begin{array}{l}40 \\
70\end{array}$ & $\begin{array}{l}44 \\
74\end{array}$ \\
\hline \multicolumn{10}{|c|}{ B: Total Mutual Savings-and-Loan Conversions } \\
\hline $\begin{array}{l}\text { No. of Conversions } \\
\text { Stock Sold (\$mil) }\end{array}$ & $\begin{array}{r}16 \\
\$ 141\end{array}$ & $\begin{array}{r}37 \\
127\end{array}$ & $\begin{array}{r}31 \\
123\end{array}$ & $\begin{array}{r}83 \\
2,741\end{array}$ & $\begin{array}{r}96 \\
715\end{array}$ & $\begin{array}{r}78 \\
1,385\end{array}$ & $\begin{array}{r}86 \\
2,484\end{array}$ & $\begin{array}{r}130 \\
1,957\end{array}$ & $\begin{array}{r}98 \\
767\end{array}$ \\
\hline
\end{tabular}

aNet worth is calculated according to generally accepted accounting principles (GAAP). During the sample period, thrift regulatory capital was calculated using regulatory accounting principles (RAP). RAP are generally less conservative than GAAP, thus, RAP-based capital is generally higher than GAAP-capital.

Sources:

Barth, Bartholomew and Bradley, 1990

Maksimovic and Unal, 1993 
Table II

Descriptive Statistics for the Converting Institutions at Time of Conversion and for the Control Samples by Year

TA is total assets. GAP/TA is the excess of assets over liabilities with contractual maturities of 12 months or less/total assets. NET/TA is the net one-year gap after impact of off-balance sheet activities/total assets. REALE is real estate held for investment/total assets. CAPITAL is tangible capital/total assets.

\begin{tabular}{|c|c|c|c|c|c|}
\hline & 1984 & 1985 & 1986 & 1987 & 1988 \\
\hline \multicolumn{6}{|c|}{ Panel A. Converting Institutions - At time of conversion } \\
\hline $\begin{array}{l}\text { No. of Institutions } \\
\text { TA (\$mil) } \\
\text { CAPITAL } \\
\text { GAP/TA } \\
\text { NET/TA } \\
\text { REALE } \\
\end{array}$ & $\begin{array}{c}19 \\
1,084 \\
2.18 \% \\
(0.4761) \\
(0.4465) \\
0.0004 \\
\end{array}$ & $\begin{array}{c}18 \\
1,785 \\
2.00 \% \\
(0.4312) \\
(0.4229) \\
0.0003 \\
\end{array}$ & $\begin{array}{c}19 \\
2,417 \\
2.46 \% \\
(0.3386) \\
(0.2945) \\
0.0009 \\
\end{array}$ & $\begin{array}{c}19 \\
1,647 \\
2.68 \% \\
(0.3725) \\
(0.3176) \\
0.0021 \\
\end{array}$ & $\begin{array}{c}6 \\
1,096 \\
3.19 \% \\
(0.2942) \\
(0.2578) \\
0.0006 \\
\end{array}$ \\
\hline
\end{tabular}

Panel B. Non-Converting Mutual Institutions

\begin{tabular}{lccccc}
\hline No. of Institutions & 100 & 106 & 112 & 118 & 123 \\
TA (\$mil) & 1,082 & 1,108 & 1,183 & 1,221 & 1,329 \\
CAPITAL & $-1.29 \%$ & $-0.45 \%$ & $0.90 \%$ & $1.05 \%$ & $1.03 \%$ \\
GAPTTA & $(0.5482)$ & $(0.4425)$ & $(0.4150)$ & $(0.4177)$ & $(0.3930)$ \\
NET/TA & $(0.5449)$ & $(0.4364)$ & $(0.4044)$ & $(0.4043)$ & $(0.3764)$ \\
REALE & 0.0013 & 0.0022 & 0.0023 & 0.0024 & 0.0026 \\
\hline
\end{tabular}

Panel C: Stock-Chartered Institutions

\begin{tabular}{lccccc}
\hline No. of Institutions & 36 & 36 & 36 & 35 & 36 \\
TA (\$mil) & 3,780 & 4,064 & 4,548 & 5,163 & 5,641 \\
CAPITAL & $1.35 \%$ & $2.08 \%$ & $2.18 \%$ & $1.59 \%$ & $0.34 \%$ \\
GAP/TA & $(0.4638)$ & $(0.3871)$ & $(0.3374)$ & $(0.3623)$ & $(0.3582)$ \\
NET/TA & $(0.4522)$ & $(0.3617)$ & $(0.3132)$ & $(0.3371)$ & $(0.3215)$ \\
REALE & 0.0134 & 0.0080 & 0.0099 & 0.0096 & 0.0084 \\
\hline
\end{tabular}


Table III

Means of Proxy Variables for Converting Institutions, Non-Converting Mutuals, and Stock Institutions ${ }^{a}$

TA is total assets. CAPITAL is tangible capital/total assets. GROWTH is the percent increase in total assets during quarter t. GAP/TA is the excess of assets over liabilities with contractual maturities of 12 months or less/total assets. NET/TA is the net one-year gap after impact of off-balance sheet activities/total assets. \% Users is the frequency of the use of derivatives. REALE is real estate held for investment/total assets.

\begin{tabular}{|c|c|c|c|c|}
\hline & Convert & $\begin{array}{l}\text { Institutions } \\
81)\end{array}$ & $\begin{array}{l}\text { Non-Converting Mutuals } \\
\qquad(\mathrm{n}=123)\end{array}$ & $\begin{array}{l}\text { Stock Institutions } \\
\qquad(\mathrm{n}=36)\end{array}$ \\
\hline & Pre-Conversi & Post-Conversion & & \\
\hline Panel A. Control & Variables & & & \\
\hline TA & $\$ 1,815,821$ & $2,363,115^{(1) b}$ & $1,162,137^{(1)\{1\}}$ & $4,494,075^{(1)}\{1\}$ \\
\hline CAPITAL & 0.0004 & $0.0319(1)$ & $0.0017^{(\mathrm{NS})}\{1\}$ & $0.0166^{(1)\{1\}}$ \\
\hline GROWTH & 0.0248 & $0.0324^{(1)}$ & $0.0174^{(1)}\{1\}$ & $0.0345^{(1)}$ (NS) \\
\hline REGION: & & & & \\
\hline West & & & $6.9 \%$ & $42.9 \%$ \\
\hline Central & & & $22.4 \%$ & $2.9 \%$ \\
\hline Northeast & & & $37.9 \%$ & $14.3 \%$ \\
\hline Southeast & & & $29.3 \%$ & $31.4 \%$ \\
\hline Southwest & & & $3.5 \%$ & $8.6 \%$ \\
\hline
\end{tabular}

Panel B. Interest-Rate-Risk Variables

\begin{tabular}{lllll}
\hline GAP/TA & -0.4485 & $-0.3245^{(1)}$ & $-0.4501^{(\mathrm{NS})}(1\}$ & $-0.3893^{(1)\{1\}}$ \\
NET/TA & -0.4325 & $-0.2933^{(1)}$ & $-0.4406^{(\mathrm{NS})\{1\}}$ & $-0.3637^{(1)\{1\}}$ \\
\% Users & $30.42 \%$ & $57.91 \%^{(1)}$ & $22.85 \%(\mathrm{NS})\{1\}$ & $47.15 \%(1)\{1\}$ \\
\hline Panel C. Credit-Risk & Variable & & & \\
\hline REALE & 0.0004 & $0.0010^{(\mathrm{NS})}$ & $0.0021^{(1)}(1)$ & $0.0112^{(1)\{1\}}$ \\
\hline
\end{tabular}

a Means are computed by first averaging each variable by quarter for each of the three samples: converting institutions, non-converting mutuals, and stock institutions. The means for the pre-conversion and postconversion samples, respectively, represent the average of the equally-weighted quarterly means over the 9 quarters from $t-9$ to $t-1$ and the 12 quarters $t+1$ through $t+12$. The means for the non-converting mutuals and stock institutions represent the average of the equally-weighted quarterly means over the 22 quarters from $t-9$ to $t+12$. This process controls for differences in the number of observations per quarter within each sample.

b Numbers in brackets indicate the significance level of a Wald test of the equality of the sample mean to that of the (pre) and \{post\} conversion samples, respectively. NS indicates the sample means are not significantly different.

c The results for REALE exclude one institution in the Southwest region which held over $15 \%$ of its assets in real estate for a portion of the sample period. On average, institutions held $0.16 \%$ of their assets in real estate. 
Table IV

Results of Pooled Regressions of Proxies for Interest-Rate Risk on Event-Time Variables for 1,328 Quarterly Observations for 81 Conversions between January 1984 and December 1988

XSGAP is the excess of GAP/TA of converting institution $\mathrm{j}$ in quarter $\mathrm{t}$ over the average GAP/TA for all stock-chartered institutions during quarter $t$. XSNET is the excess of NET/TA of converting institution $j$ in quarter $t$ over the average NET/TA for all stock-chartered institutions during quarter $t$. XSREALE is the excess of REALE of converting institution $j$ in quarter $t$ over the average REALE for all stock-chartered institutions during quarter $t$. Time $(t+k)$ equals 1 if the quarter $t$ is $k$ quarters from the conversion quarter of institution $j$; equals 0 otherwise. This Table shows the estimation of equation (1):

$$
\text { Equation (1): } \quad \operatorname{RISK}_{\mathrm{jt}}=\alpha+\sum_{\mathrm{k}=-9}^{12} \beta_{\mathrm{k}} \operatorname{Time}(\mathrm{t}+\mathrm{k})+\sum_{\mathrm{r}=1}^{5} \delta_{\mathrm{k}} \operatorname{Region}_{\mathrm{r}}+\mathrm{e}_{\mathrm{jt}}
$$

\begin{tabular}{|c|c|c|c|c|}
\hline \multirow[b]{3}{*}{ Intercept } & \multirow[b]{2}{*}{ No. of obs. $=1$} & \multicolumn{2}{|c|}{-Proxies for Interest-Rate RISK--.-. } & \multirow{2}{*}{$\begin{array}{l}\text { Proxy for Credit RISK } \\
\text { XSREALE }\end{array}$} \\
\hline & & XSGAP & XSNET & \\
\hline & & $-0.0702 * *$ & $-0.0659 * *$ & $-0.0117 * *$ \\
\hline $\mathrm{t}-9$ & 31 & -0.0204 & -0.0239 & $-0.0028 * *$ \\
\hline$t-8$ & 31 & -0.0200 & -0.0230 & $-0.0018 *$ \\
\hline $\mathrm{t}-7$ & 40 & -0.0211 & -0.0198 & $-0.0018 *$ \\
\hline$t-6$ & 40 & -0.0201 & -0.0203 & -0.0011 \\
\hline$t-5$ & 41 & -0.0204 & -0.0141 & -0.0009 \\
\hline$t-4$ & 47 & -0.0034 & 0.0034 & 0.0003 \\
\hline $\mathrm{t}-3$ & 49 & 0.0082 & 0.0176 & 0.0002 \\
\hline$t-2$ & 51 & -0.0018 & 0.0250 & -0.0000 \\
\hline $\mathrm{t}-1$ & 54 & -0.0037 & 0.0324 & -0.0002 \\
\hline timet & 64 & 0.0278 & $0.0533 * *$ & -0.0004 \\
\hline$t+1$ & 64 & 0.0180 & $0.0352 *$ & -0.0007 \\
\hline$t+2$ & 64 & 0.0220 & $0.0457 * *$ & 0.0001 \\
\hline$t+3$ & 65 & 0.0308 & $0.0604 * *$ & $0.0014 *$ \\
\hline$t+4$ & 67 & 0.0328 & $0.0604 * *$ & $0.0014 *$ \\
\hline$t+5$ & 69 & 0.0445 & $0.0664 * *$ & $0.0014 *$ \\
\hline$t+6$ & 69 & $0.0482 * *$ & $0.0639 * *$ & $0.0020 * *$ \\
\hline$t+7$ & 60 & $0.0507 * *$ & $0.0723 * *$ & $0.0028 * *$ \\
\hline$t+8$ & 52 & $0.0495 * *$ & $0.0629 * *$ & $0.0023 * *$ \\
\hline$t+9$ & 40 & $0.0642^{* *}$ & $0.0745 * *$ & $0.0018^{*}$ \\
\hline$t+10$ & 35 & 0.0318 & 0.0388 & $0.0024 * *$ \\
\hline$t+11$ & 32 & 0.0279 & 0.0381 & $0.0030^{* *}$ \\
\hline$t+12$ & 33 & 0.0322 & 0.0323 & $0.0030^{* *}$ \\
\hline $\mathrm{Wcst}^{\mathrm{a}}$ & 212 & $0.1185^{* *}$ & $0.1037 * *$ & 0.0014 \\
\hline Central ${ }^{a}$ & 165 & $0.0429 *$ & $0.0770 * *$ & $0.0015^{*}$ \\
\hline Northeast ${ }^{\mathrm{a}}$ & 526 & $0.0480 * *$ & 0.0278 & 0.0009 \\
\hline Southeast $^{\mathrm{a}}$ & 367 & $0.0418 *$ & 0.0109 & 0.0007 \\
\hline Adjusted $\mathrm{R}^{2}$ & & $6.7 \%$ & $10.9 \%$ & $6.1 \%$ \\
\hline
\end{tabular}

$* *(*)$ Significant at the $1 \%(5 \%)$ level, respectively, two-tail test.

${ }^{\mathrm{a}}$ The number of institutions in each region is:

$\begin{array}{ll}\text { West } & 12 \\ \text { Central } & 10 \\ \text { Northeast } & 34 \\ \text { Southeast } & 24\end{array}$

The Central region excludes one institution in the state of Illinois. One institution of the two in the Southwest region which held over $15 \%$ of its assets in real estate for a portion of the sample period is also excluded. On average, institutions held $0.16 \%$ of their assets in real estate. 
Table V

Descriptive Statistics of THETA, INSIDE and OPTS

THETA is Ex ante growth opportunities measured at conversion. INSIDE is the percentage of the initial public offering purchased by insiders at conversion. OPTS is the ratio of the number of options granted to management at conversion relative to the total number of shares issued at conversion.

\begin{tabular}{lcccc}
\hline \hline & Mean & Standard Deviation & Median & Maximum \\
\cline { 2 - 5 } THETA & 0.9189 & 0.0843 & 0.875 & 0.845 \\
INSIDE & 0.0457 & 0.0395 & 0.031 & 0.150 \\
OPTS & 0.0183 & 0.0352 & 0.000 & 0.171 \\
\end{tabular}

Histograms of the Frequency of Observations of THETA, Inside Share Ownership and Managerial Stock Options
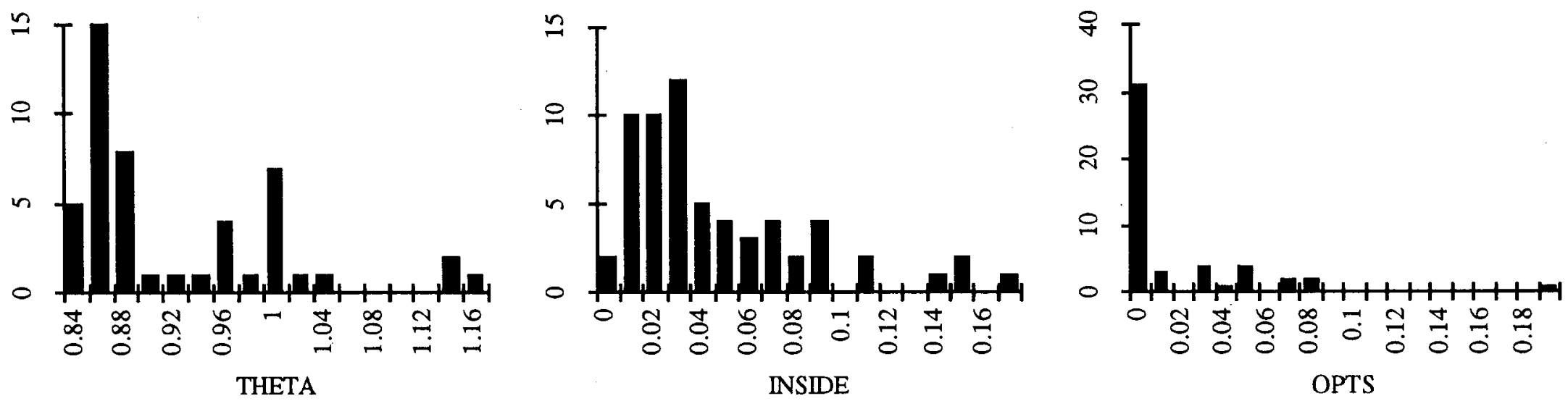
Table VIa

Tests of the Association Between Interest-Rate Risk and Credit Risk and Ex Ante Growth Opportunities and Managerial Share Holdings

XSNET is the excess of NET/TA of converting institution $j$ in quarter $t$ over the average NET/TA for all stock-chartered institutions during quarter $t$. Time( $t+k$ ) is equal to 1 if the quarter $\mathrm{t}$ is $\mathrm{k}$ quarters from the conversion quarter of institution $\mathrm{j} ;=0$ otherwise. THETA is the proxy forex ante growth opportunities measured by the chosen issue price at conversion relative to the midpoint of the conversion appraisal range. INSIDE is the percentage of the initial public offering purchased by insiders at conversion.

\begin{tabular}{|c|c|c|c|c|c|c|c|c|}
\hline \multirow[b]{4}{*}{ MODEL: } & \multicolumn{8}{|c|}{ RISK $=\alpha+\sum_{k=-9}^{12} \beta_{k} \operatorname{Time}(t+k)+e_{j t}$} \\
\hline & \multicolumn{2}{|c|}{ RISK $=$ XSNET } & \multicolumn{2}{|c|}{ RISK $=$ XSREALE } & \multicolumn{2}{|c|}{ RISK $=$ XSNET } & \multicolumn{2}{|c|}{ RISK = XSREALE } \\
\hline & $\begin{array}{c}\text { THETA } \geq 1 \\
(n=17)\end{array}$ & $\begin{array}{c}\text { THETA }<1 \\
(n=45)\end{array}$ & $\begin{array}{c}\text { THETA } \geq 1 \\
(\mathrm{n}=17)\end{array}$ & $\begin{array}{c}\text { THETA }<1 \\
(\mathrm{n}=45)\end{array}$ & $\begin{array}{c}\text { INSIDE } \\
\text { LOW }(n=39)\end{array}$ & $\begin{array}{c}\text { INSIDE } \\
\text { HIGH }(n=40)\end{array}$ & $\begin{array}{c}\text { INSIDE } \\
\text { LOW }(n=39)\end{array}$ & $\begin{array}{c}\text { INSIDE } \\
\text { HIGH }(\mathrm{n}=40)\end{array}$ \\
\hline & $(1)$ & $(2)$ & (3) & $(4)$ & $(5)$ & $(6)$ & $(7)$ & $(8)$ \\
\hline Intercept & $-0.0972 * *$ & $-0.0264 * * \dagger$ & $-0.0128 * *$ & $-0.0096^{* * \dagger}$ & -0.0075 & $-0.0441 * * \dagger$ & $-0.0115^{* *}$ & $-0.0103^{* *}$ \\
\hline $\mathrm{t}-9$ & 0.0923 & -0.0116 & -0.0025 & $-0.0034 * *$ & -0.0505 & 0.0100 & $-0.0027 *$ & -0.0022 \\
\hline$t-8$ & 0.0805 & -0.0184 & -0.0019 & -0.0024 & -0.0562 & 0.0212 & -0.0012 & -0.0020 \\
\hline$t-7$ & 0.1167 & $-0.0293 \dagger$ & -0.0011 & $-0.0029 *$ & -0.0539 & $0.0291 \dagger$ & -0.0010 & -0.0022 \\
\hline$t-6$ & 0.0811 & -0.0181 & -0.0008 & -0.0023 & -0.0614 & $0.0361 \dagger$ & -0.0004 & -0.0014 \\
\hline$t-5$ & 0.0858 & -0.0074 & -0.0012 & -0.0015 & -0.0551 & $0.0382 \dagger$ & 0.0003 & -0.0018 \\
\hline$t-4$ & $0.1152 *$ & $0.0106 \dagger$ & 0.0007 & -0.0005 & -0.0334 & $0.0555 * \dagger$ & 0.0015 & -0.0008 \\
\hline$t-3$ & $0.1090 *$ & 0.0311 & 0.0012 & -0.0007 & -0.0183 & $0.0650 * \dagger$ & 0.0017 & -0.0008 \\
\hline$t-2$ & $0.1475^{* *}$ & $0.0222 \dagger$ & 0.0015 & -0.0010 & -0.0041 & $0.0665^{* * \dagger}$ & 0.0016 & $-0.0012 \dagger$ \\
\hline$t-1$ & $0.1504 * *$ & $0.0319 \dagger$ & 0.0018 & -0.0014 & 0.0059 & $0.0619 *$ & 0.0013 & -0.0011 \\
\hline timet & $0.1813 * *$ & $0.0510 * \dagger$ & 0.0033 & $-0.0023 * \dagger$ & 0.0401 & $0.0575^{*}$ & 0.0008 & -0.0012 \\
\hline$t+1$ & $0.1627 * *$ & $0.0246 \dagger$ & 0.0028 & $-0.0027 * * \dagger$ & 0.0232 & 0.0321 & 0.0003 & -0.0015 \\
\hline$t+2$ & $0.1550 * *$ & $0.0477 \dagger$ & $0.0053 *$ & $-0.0026 * * \dagger$ & 0.0305 & $0.0497 *$ & 0.0006 & -0.0002 \\
\hline$t+3$ & $0.1789 * *$ & $0.0562 * t$ & $0.0065^{* *}$ & $-0.0006 \dagger$ & 0.0467 & $0.0639 * *$ & $0.0020^{*}$ & 0.0013 \\
\hline$t+4$ & $0.1717^{* *}$ & $0.0597 * \dagger$ & $0.0058^{*}$ & $-0.0005 t$ & 0.0456 & $0.0677 * *$ & 0.0017 & 0.0014 \\
\hline$t+5$ & $0.1834 * *$ & $0.0636 * * \dagger$ & $0.0058 *$ & $-0.0006 \dagger$ & 0.0484 & $0.0796^{* *}$ & 0.0015 & 0.0017 \\
\hline$t+6$ & $0.1705^{* *}$ & $0.0615 * * \dagger$ & $0.0065 * *$ & $-0.0001 \uparrow$ & $0.0563 *$ & $0.0643 * *$ & $0.0021 *$ & $0.0023 *$ \\
\hline$t+7$ & $0.1600^{* *}$ & $0.0737 * *$ & $0.0065 * *$ & $0.0013 \dagger$ & $0.0665^{*}$ & $0.0789 * *$ & $0.0029 * *$ & $0.0034 * *$ \\
\hline$t+8$ & $0.1397 * *$ & $0.0701 * *$ & 0.0032 & 0.0016 & $0.0739 *$ & $0.0556 * \dagger$ & $0.0029 * *$ & 0.0022 \\
\hline$t+9$ & $0.1615^{* *}$ & $0.0693 *$ & 0.0031 & 0.0013 & $0.0835^{*}$ & $0.0726 * * \dagger$ & $0.0024 *$ & 0.0018 \\
\hline$t+10$ & $0.1432 *$ & $0.0255 \dagger$ & 0.0034 & 0.0020 & 0.0278 & 0.0532 & $0.0027 *$ & $0.0025^{*}$ \\
\hline$t+11$ & $0.1288^{*}$ & 0.0274 & 0.0038 & $0.0030 *$ & 0.0317 & 0.0483 & $0.0049 * *$ & 0.0020 \\
\hline$t+12$ & $0.1264^{*}$ & $0.0183 \dagger$ & 0.0040 & $0.0028 *$ & 0.0143 & 0.0478 & $0.0053 * *$ & $0.0017 \dagger$ \\
\hline Adjusted $\mathrm{R}^{2}$ & $2.0 \%$ & $2.1 \%$ & $8.4 \%$ & $6.0 \%$ & $4.9 \%$ & $2.2 \%$ & $6.1 \%$ & $5.0 \%$ \\
\hline
\end{tabular}

** $\left({ }^{*}\right)$ Significant at the $1 \%(5 \%)$ level, respectively, two-tail test.

$\dagger \quad$ Significantly different at the $10 \%$ level from the coefficient estimate in the preceding column where the coefficients are estimated in a single regression equation. 
Tests of the Association Between Interest-Rate Risk and Credit Risk and Managerial Stock Options

XSNET is the excess of NET/TA of converting institution $\mathrm{j}$ in quarter $\mathrm{t}$ over the average NET/TA for all stock-chartered institutions during quarter $t$. Time $(t+k)$ is equal to 1 if the quarter $t$ is $k$ quarters from the conversion quarter of institution $j ;=0$ otherwise. OPTS is the ratio of the number of options granted to management at conversion relative to the total number of shares issued at conversion.

\begin{tabular}{|c|c|c|c|c|c|c|}
\hline \multicolumn{7}{|c|}{$\operatorname{RISK}=\alpha+\sum_{\mathrm{k}=-9}^{12} \beta_{\mathrm{k}} \operatorname{Time}(\mathrm{t}+\mathrm{k})+\xi_{\mathrm{jt}}$} \\
\hline & \multicolumn{3}{|c|}{ RISK = XSNET } & \multicolumn{3}{|c|}{ RISK = XSREALE } \\
\hline & $\begin{array}{l}\text { OPTS }=0 \\
(\mathrm{n}=35)\end{array}$ & $\begin{aligned} \text { OPTS } & =\mathrm{LOW} \\
(\mathrm{n} & =13)\end{aligned}$ & $\begin{array}{c}\begin{array}{c}\text { OPTS }=\text { HIGH } \\
(\mathrm{n}=14)\end{array} \\
\end{array}$ & $\begin{array}{l}\text { OPTS }=0 \\
(\mathrm{n}=35)\end{array}$ & $\begin{aligned} & \text { OPTS }=\text { LOW } \\
&(\mathrm{n}=13)\end{aligned}$ & $\begin{array}{c}\mathrm{OPTS}=\mathrm{HIGH} \\
(\mathbf{n}=14)\end{array}$ \\
\hline MODEL: & $(1)$ & $(2)$ & (3) & (4) & $(5)$ & $(6)$ \\
\hline Intercept & $-0.0376 * *$ & -0.0300 & -0.0190 & $-0.0110^{* *}$ & $-0.0107 * *$ & $-0.0058 * * \dagger$ \\
\hline$t-9$ & 0.0295 & -0.0141 & -0.0842 & $-0.0033^{* *}$ & -0.0009 & -0.0077 \\
\hline$t-8$ & 0.0167 & -0.0161 & -0.0818 & $-0.0024 *$ & -0.0005 & -0.0058 \\
\hline$t-7$ & 0.0085 & 0.0359 & -0.1003 & $-0.0018 *$ & -0.0026 & $-0.0071 \dagger$ \\
\hline$t-6$ & 0.0034 & 0.0255 & -0.0797 & -0.0015 & -0.0018 & -0.0060 \\
\hline$t-5$ & 0.0160 & 0.0247 & -0.0662 & $-0.0019 *$ & -0.0007 & -0.0034 \\
\hline$t-4$ & 0.0146 & 0.0892 & -0.0118 & -0.0002 & -0.0002 & -0.0035 \\
\hline $\mathrm{t}-3$ & 0.0298 & 0.0715 & 0.0292 & -0.0000 & 0.0001 & -0.0042 \\
\hline $\mathrm{t}-2$ & 0.0292 & $0.1013^{*}$ & 0.0161 & 0.0004 & -0.0012 & $-0.0043 \dagger$ \\
\hline $\mathrm{t}-1$ & 0.0454 & $0.0893 *$ & 0.0222 & -0.0003 & -0.0012 & -0.0028 \\
\hline timet & 0.0580 & $0.1195 * *$ & 0.0601 & -0.0006 & -0.0007 & $-0.0046 \dagger$ \\
\hline$t+1$ & 0.0384 & 0.0690 & 0.0496 & -0.0012 & -0.0002 & $-0.0054 \dagger$ \\
\hline$t+2$ & 0.0370 & $0.1018 *$ & $0.1040^{*}$ & -0.0008 & -0.0002 & -0.0027 \\
\hline$t+3$ & 0.0511 & $0.1271^{* *}$ & $0.0924^{*}$ & 0.0004 & 0.0008 & 0.0015 \\
\hline$t+4$ & $0.0657 *$ & $0.1022 *$ & 0.0711 & 0.0008 & 0.0007 & -0.0009 \\
\hline$t+5$ & $0.0732 *$ & $0.1166^{* *}$ & 0.0733 & 0.0010 & 0.0010 & -0.0016 \\
\hline$t+6$ & $0.0724 *$ & $0.1006^{*}$ & 0.0672 & $0.0017 * *$ & 0.0013 & -0.0009 \\
\hline$t+7$ & $0.0917 * *$ & $0.1096^{* *}$ & 0.0394 & $0.0023^{* *}$ & 0.0024 & 0.0009 \\
\hline$t+8$ & $0.0841 * *$ & 0.0814 & 0.0470 & $0.0020 * *$ & $0.0050 *$ & $-0.0032 \dagger$ \\
\hline$t+9$ & $0.0962 * *$ & $0.1169^{*}$ & 0.0169 & $0.0016^{*}$ & $0.0044 *$ & $-0.0033 \dagger$ \\
\hline$t+10$ & 0.0510 & 0.0909 & -0.0000 & $0.0023^{* *}$ & $0.0063 * *$ & $-0.0033 \gamma$ \\
\hline$t+11$ & 0.0393 & 0.0665 & 0.0324 & $0.0021 *$ & $0.0052 *$ & 0.0004 \\
\hline$t+12$ & 0.0278 & 0.0911 & 0.0130 & $0.0019 *$ & $0.0050 *$ & 0.0006 \\
\hline Adjusted $\mathrm{R}^{2}$ & $0.10 \%$ & $4.4 \%$ & $5.6 \%$ & $13.0 \%$ & $5.5 \%$ & $-5.6 \%$ \\
\hline
\end{tabular}


Table VII

Cross-Sectional Tests of the Association between Interest-Rate Risk (XSGAP and XSNET) and Credit Risk (XSREALE) Partitioned by the Cross-Sectional Determinants of Total Risk ${ }^{\mathrm{a}}$

XSGAP (XSNET) (XSREALE\} is the excess of GAP/TA (NET/TA) \{REALE) of converting institution $\mathrm{j}$ in quarter t over the average GAP/TA (NET/TA) \{REALE\} for all stock-chartered institutions during quarter t. THETA is ex ante growth opportunities at conversion. INSIDE is the percentage of the initial public offering purchased by insiders at conversion. OPTS is the ratio of the number of options granted to management relative to the total number of shares issued at conversion. The equations estimated are:

$$
\begin{array}{ll}
\text { Equation (2): } & \operatorname{XSNET~}_{\mathrm{jt}}=\delta_{\mathrm{I}}+\delta_{\mathrm{R}} \mathrm{XSREALE}_{\mathrm{jt}}+\varepsilon_{\mathrm{jt}} \\
\text { Equation (3): } & \operatorname{XSGAP}_{\mathrm{jt}}=\delta_{\mathrm{I}}+\delta_{\mathrm{R}} \mathrm{XSREALE}_{\mathrm{jt}}+\varepsilon_{\mathrm{jt}} \\
\text { Equation (4): } & \operatorname{XSNET}_{\mathrm{jt}}=\delta_{\mathrm{I}}+\delta_{\mathrm{G}} \mathrm{XSGAP}_{\mathrm{jt}}+\delta_{\mathrm{R}} \mathrm{XSREALE}_{\mathrm{jt}}+\varepsilon_{\mathrm{jt}}
\end{array}
$$

\begin{tabular}{|c|c|c|c|c|c|c|c|c|}
\hline \multirow[b]{2}{*}{ Model } & $\begin{array}{c}\text { Pre- } \\
\text { Conversion }\end{array}$ & $\begin{array}{c}\text { Post- } \\
\text { Conversion }\end{array}$ & $\begin{array}{c}\text { Pre- } \\
\text { Conversion }\end{array}$ & $\begin{array}{c}\text { Post- } \\
\text { Conversion }\end{array}$ & $\begin{array}{c}\text { Pre- } \\
\text { Conversion }\end{array}$ & $\begin{array}{c}\text { Post- } \\
\text { Conversion }\end{array}$ & \multirow{2}{*}{$\begin{array}{l}\text { Adj. } \\
\mathrm{R}^{2}\end{array}$} & \multirow[b]{2}{*}{ F-Test ${ }^{b}$} \\
\hline & \multicolumn{2}{|c|}{ INTERCEPT } & \multicolumn{2}{|c|}{ XSGAP } & \multicolumn{2}{|c|}{ XSREALE } & & \\
\hline & \multicolumn{8}{|c|}{ Panel A: Growth Possibilities (THETA) } \\
\hline $\begin{array}{l}\theta \geq 1 \text { : } \\
\text { Eqn. (2) } \\
\text { Eqn. (3) } \\
\text { Eqn. (4) }\end{array}$ & $\begin{array}{c}0.049 \\
-0.034 \\
0.073 *\end{array}$ & $\begin{array}{l}0.104^{* *} \\
0.100^{* *} \\
0.023^{*}\end{array}$ & $0.722 * * \dagger \dagger$ & $0.804 * * \dagger \dagger$ & $\begin{array}{c}2.536 \\
-3.409 \\
4.997 *\end{array}$ & $\begin{array}{l}4.995^{* *} \\
6.764^{* *} \\
-0.443\end{array}$ & $\begin{array}{r}5.9 \\
8.8 \\
60.0\end{array}$ & $\begin{array}{l}0.37(0.54) \\
5.50(0.02) \\
6.01(0.02)\end{array}$ \\
\hline $\begin{array}{l}\theta<1 \text { : } \\
\text { Eqn. (2) } \\
\text { Eqn. (3) } \\
\text { Eqn. (4) }\end{array}$ & $\begin{array}{l}0.059 * \\
0.000 \\
0.058^{* *}\end{array}$ & $\begin{array}{c}0.011 \\
-0.015 \\
0.024 * *\end{array}$ & $0.936 * *$ & $0.844 * * \dagger \dagger$ & $\begin{array}{l}7.134 * * \\
2.780 \\
4.530^{* *}\end{array}$ & $\begin{array}{l}-1.472 \\
-2.796 \\
0.889 *\end{array}$ & $\begin{array}{r}4.0 \\
2.4 \\
81.6\end{array}$ & $\begin{array}{r}10.14(0.00) \\
3.55(0.06) \\
8.70(0.00)\end{array}$ \\
\hline Eqn. (4) & \multicolumn{8}{|c|}{ Panel B: Managerial Share Ownership (INSIDE) } \\
\hline $\begin{array}{l}\text { HIGH: } \\
\text { Eqn. (2) } \\
\text { Eqn. (3) } \\
\text { Eqn. (4) }\end{array}$ & $\begin{array}{r}-0.019 \\
0.008 \\
-0.027\end{array}$ & $\begin{array}{l}0.045^{* *} \\
0.056^{* *} \\
-0.006^{*}\end{array}$ & $0.988 * *$ & $0.920 * * \dagger \dagger$ & $\begin{array}{l}-1.892 \\
-0.357 \\
-1.539\end{array}$ & $\begin{array}{l}3.274 * * \\
3.718 * * \\
-0.147\end{array}$ & $\begin{array}{r}1.7 \\
2.1 \\
87.9\end{array}$ & $\begin{array}{l}2.65(0.10) \\
1.79(0.18) \\
0.82(0.37)\end{array}$ \\
\hline $\begin{array}{l}\text { LOW: } \\
\text { Eqn. (2) } \\
\text { Eqn. (3) } \\
\text { Eqn. (4) }\end{array}$ & $\begin{array}{l}0.071^{* *} \\
-0.006 \\
0.076^{* *}\end{array}$ & $\begin{array}{l}0.020 \\
-0.021 \\
0.037 * *\end{array}$ & $0.858 * * \dagger \dagger$ & $0.820 * * \dagger \dagger$ & $\begin{array}{c}10.026^{* *} \\
4.089 \\
6.520^{* *}\end{array}$ & $\begin{array}{l}-2.061 \\
-3.776 \\
1.034\end{array}$ & $\begin{array}{r}9.8 \\
5.4 \\
75.5\end{array}$ & $\begin{array}{r}13.78(0.00) \\
4.01(0.04) \\
29.54(0.00)\end{array}$ \\
\hline & \multicolumn{8}{|c|}{ Panel C: Executive Stock } \\
\hline $\begin{array}{l}\text { HIGH: } \\
\text { Eqn. (2) } \\
\text { Eqn. (3) } \\
\text { Eqn. (4) }\end{array}$ & $\begin{array}{l}-0.020 \\
-0.137 * * \\
0.094 * *\end{array}$ & $\begin{array}{l}0.063^{* *} \\
0.026^{*} \\
0.047^{* *}\end{array}$ & $0.827 * *$ & $0.638 * * \dagger^{\dagger \dagger}$ & $\begin{array}{l}2.550 \\
-4.653^{*} \\
6.397^{* *}\end{array}$ & $\begin{array}{l}3.904^{* *} \\
5.070^{* *} \\
0.669 *\end{array}$ & $\begin{array}{l}15.3 \\
14.9 \\
69.2\end{array}$ & $\begin{array}{r}0.38(0.54) \\
16.33(0.00) \\
59.49(0.00)\end{array}$ \\
\hline $\begin{array}{l}\text { LOW: } \\
\text { Eqn. (2) } \\
\text { Eqn. (3) } \\
\text { Eqn. (4) }\end{array}$ & $\begin{array}{r}0.000 \\
-0.051 \\
0.038\end{array}$ & $\begin{array}{l}0.036^{*} \\
0.026 \\
0.018^{*}\end{array}$ & $0.731 * *$ & $0.694 * * \dagger \dagger$ & $\begin{array}{r}-1.936 \\
-5.720 \\
2.248\end{array}$ & $\begin{array}{l}-3.973^{*} \\
-2.950 \\
-1.926^{*}\end{array}$ & $\begin{array}{r}3.5 \\
2.0 \\
50.7\end{array}$ & $\begin{array}{l}0.23(0.63) \\
0.44(0.51) \\
4.06(0.05)\end{array}$ \\
\hline $\begin{array}{l}\text { NONE: } \\
\text { Eqn. (2) } \\
\text { Eqn. (3) } \\
\text { Eqn. (4) }\end{array}$ & $\begin{array}{l}0.117^{* *} \\
0.095^{* *} \\
0.026\end{array}$ & $\begin{array}{l}0.022 \\
0.011 \\
0.012\end{array}$ & $0.961 * *$ & $0.946 * * \dagger \dagger$ & $\begin{array}{l}11.008^{* *} \\
9.204 * * \\
2.165\end{array}$ & $\begin{array}{r}-0.185 \\
-1.082 \\
0.838\end{array}$ & $\begin{array}{r}3.4 \\
2.8 \\
86.5\end{array}$ & $\begin{array}{l}6.45(0.01) \\
5.70(0.02) \\
0.57(0.45)\end{array}$ \\
\hline
\end{tabular}

$* *(*)$ Significantly different from zero at the $1 \%(5 \%)$ level, respectively, two-tail test.

$\dagger \dagger(\dagger)$ Significantly different from unity at the $1 \%(5 \%)$ level, respectively, two-tail test.

${ }^{\text {a }}$ Test statistics are calculated using the White estimator for the covariance matrix of the least squares estimators.

${ }^{b}$ F-test of the equality of the pre and post-conversion coefficient estimates on XSREALE (p-value in parentheses). 